\title{
Biostratigraphy, sequence stratigraphy and gamma-ray spectrometry of the Tournaisian-Viséan boundary interval in the Dublin Basin
}

\author{
JiŘí Kalvoda, OndŘej BÁbeK, François X. DeVuyst \& GeOrge D. SeVAstopulo
}

\begin{abstract}
A study of three carbonate and carbonate-siliciclastic sections at the Tournaisian-Viséan (Tn-V) boundary in the Dublin Basin (Ireland), has been carried out using high resolution foraminiferal biostratigraphy and gamma-ray spectrometry. The aim was to identify the Tn-V boundary and trace correlatable log patterns in different environmental settings of the Dublin Basin. The foraminiferal fauna in the heterozoan and mixed heterozoan-photozoan (foramderm and bryonoderm extended) late Tournaisian shallow ramp facies and its calciturbidite products is taxonomically impoverished and resembles the similar impoverished foraminiferal associations of western Canada interpreted as reflecting upwelling zones. The increase of photozoan bioclasts which occurs in the latest Tournaisian is accompanied by the entry of important foraminiferal guides of the $\mathrm{Tn}-\mathrm{V}$ boundary interval. The combination of biostratigraphic and spectral gamma-ray data proved to be a useful tool for the identification of the sequence boundary just below the Tn-V boundary across the different environmental settings of the Dublin Basin. The recognized sea-level fall is correlatable across the London Brabant Massif from western Ireland through to England, South Wales and Belgium. - Key words: Tournaisian, Viséan, biostratigraphy, sequence stratigraphy, gamma-ray spectrometry.
\end{abstract}

Kalvoda, J., BÁBeK, O., Devuyst, F.X. \& Sevastopulo, G.D. 2011. Biostratigraphy, sequence stratigraphy and gamma-ray spectrometry of the Tournaisian-Viséan boundary interval in the Dublin Basin. Bulletin of Geosciences 86(4), 683-706 (13 figures). Czech Geological Survey, Prague. ISSN 1214-1119. Manuscript received March 17, 2011; accepted in revised form April 26, 2011; published online June 15, 2011; issued November 16, 2011.

Jiři Kalvoda, Institute of Geological Sciences, Masaryk University, Kotlářská 2, 61137 Brno, Czech Republic; jkalvoda@centrum.cz•Ondřej Bábek, the same address as the first author, and Department of Geology, Palacký University, Tr. 17. listopadu 12, 77200 Olomouc, Czech Republic • François X. Devuyst, Carmeuse Lime and Stone, Technology Center, 3600 Neville Road, Pittsburgh PA 15225, USA • George D. Sevastopulo, Department of Geology, Trinity College Dublin, Dublin 2, Ireland

The definition of the base of the Viséan that was utilised in the last decades of the 20th century was proposed by Raphael Conil at the $6^{\text {th }}$ International Congress of the Carboniferous System in Sheffield (UK). The proposed level coincided in the Bastion stratotype section in the Dinant basin in Belgium with the first occurrence of the calcareous foraminiferal genus Eoparastaffella (Conil et al. 1969). However, the choice of the stratotype was not ideal as the entry of stratigraphically significant foraminifers is facially controlled in a peri-Waulsortian context and many taxa regarded by Conil as Viséan guide fossils occurr elsewhere significantly earlier (Kalvoda 1982, 1983). Later it was also found that in the Belgian sections some assemblages of foraminifers that were originally considered as Viséan occur below the entry of Eoparastaffella (Conil et al. 1989, 1991; Hance et al. 1994). The use of the first occurrence of the genus Eoparastaffella as the criterion for recognition of the Tournaisian/Viséan boundary was also unsatisfactory because the most primitive representatives of the genus already appear in the late Tournaisian (Hance 1997). Subsequent research resulted in the identification of the Pengchong section (Guangxi, southern China) as a potential candidate for a new stratotype because of the exceptional record of Eoparastaffella and continuous sedimentation (Hance 1997, Hance et al. 1997, Devuyst et al. 2003). The definition of the base of the Viséan at the first appearance of the foraminifer Eoparastaffella simplex in the lineage Eoparastaffella ovalis Vdovenko-Eoparastaffella simplex and the GSSP in the Pengchong section near Liuzhou in Guangxi, southern China have been proposed (Devuyst et al. 2003) and recently ratified by the ICS and IUGS (Work 2008).

The definition of the regional stages for Britain and Ireland proposed by George et al. (1976) capitalized on the widespread application of foraminiferal biostratigraphy introduced to Western Europe by Raphael Conil (Conil \& Lys 1964, Conil et al. 1980, Paproth et al. 1983). The base of the regional Chadian stage was chosen to be coincident 
with the entry of the foraminiferan genus Eoparastaffella, supposedly in conformity with the definition of the base of the Viséan in Belgium. However, as is the case in the Bastion section (Belgium), the entry of Eoparastaffella in the Chadian type-section occurs in peri-Waulsortian facies with a discontinuous foraminiferal record. In addition, it is now known that Eoparastaffella does not appear at the base of the Chadian in the stratotype section but at a significantly higher horizon (Riley 1995).

The task of identifying the base of the Viséan in Ireland is in its infancy. In the past the base has commonly been identified at an horizon substantially older than its true recent position (Sevastopulo \& Wyse Jackson 2009). Moreover, the foraminiferal record in the latest Tournaisian-earliest Viséan has been rather poor (Jones \& Somerville 1996). Mamet (1969) described Lower Carboniferous foraminiferal associations in the Rush section of the Dublin Basin but did not identify the base of the Viséan. Late Tournaisian-early Viséan foraminiferal associations and Eoparastaffella simplex were illustrated in Ireland for the first time by Marchant (1974) and Conil \& Lees (1975). Similar associations were then mentioned by Strogen et al. (1990) in the Dublin Basin, Somerville et al. (1992) in the Limerick syncline and Strogen et al. (1995) in the Kingscourt Outlier. Devuyst (2006) outlined the distribution of the main foraminiferal guides, including E. simplex, across the Tn-V boundary in the Rush and Lane sections and gave a detailed account of the foraminifers present in the same interval in the Oughterard area, County Galway.

The sequence stratigraphic model of the Lower Carboniferous of the Namur-Dinant Basin (Belgium) was proposed by Hance et al. (2001) and correlated with northern France and the British Isles by Hance et al. (2002) and Devuyst (2006). The model largely benefited from the advances in foraminiferal biostratigraphy and previous sedimentary models by Ramsbottom (1973) and Conil et al. (1977). The boundary between sequences 4 and 5 that falls in the very latest Tournaisian (uppermost part of MFZ 8) is commonly marked by unconformities in shallower sedimentary environments where it thus approximates the Tn-V boundary (Poty et al. 2006).

Gamma-ray spectrometry (GRS) has proved a useful tool to supplement biostratigraphy and sequence stratigraphy and improves dramatically the resolution of correlations at the scale of a basin (Doveton 1994; Rider 1999; Thibal et al. 1999; Delius et al. 2001; Hladil et al. 2006).

The present study aims at improving the resolution of the biostratigraphy and sequence stratigraphy of late Tournaisian and early Viséan rocks of the Dublin Basin by combining high-resolution foraminifer biostratigraphy, sedimentology and petrophysical methods (GRS). The Rush and Lane sections were re-sampled in detail and a new section at Bay Lane Quarry was also included.

\section{Geological setting}

The Dublin Basin (Fig. 1) is one of several sedimentary basins in Britain and Ireland, which were controlled by Caledonian structures that were reactivated during the Lower Carboniferous (Phillips \& Sevastopulo 1986, Nolan 1989, Pickard et al. 1994, Strogen et al. 1996). The Lower Palaeozoic basement is overlain unconformably by Lower Carboniferous rocks. The lower part of the succession records an overall deepening trend, culminating in the latest Tournaisian with Waulsortian facies carbonate mounds and overlying deep water mudstones of the Tober Colleen Formation. On the Balbriggan platform to the north, the time equivalents are shallow water limestones of the Lane Formation. During the Viséan, relatively deep water sediments, mostly calciturbidites and shales were deposited in the basin, while the Balbriggan platform was covered by shallow water or was emergent and varied skeletal and oolitic carbonates were deposited (Fig. 1) (Somerville et al. 1992a, b; Pickard et al. 1994; Sevastopulo \& Wyse Jackson 2009).

The present study has focussed on three sections, the Lane coastal section representing the shelf facies and the Rush coastal and Bay Lane Quarry sections representing the basinal facies.

\section{The Lane coastal section}

The section is located about $1.5 \mathrm{~km}$ north of the village of Loughshinny, and about $25 \mathrm{~km}$ north-northeast of Dublin,

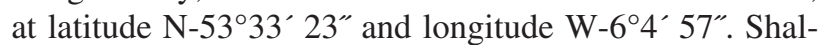
low-water shelf sedimentation of the Lane Formation of latest Tournaisian age displays a general coarsening and shallowing-upwards sequence with increasing proportion of sand. A sudden relative sea-level fall resulted in the deposition of a coarse fluviatile conglomerate (Smuggler's Cave Formation) with reworked clasts of the Lane Formation at its base. The Smuggler's Cave Formation is overlain by the Arundian Holmpatrick Formation. The Lane section has been the subject of several biostratigraphical and sedimentological studies (Devuyst 2006; Marchant 1974, 1978; Nolan 1986, 1989; these papers contain references to earlier literature). The interval sampled covers the upper part of the Lane Formation $(15 \mathrm{~m})$ and the basal Smuggler's Cave Formation.

\section{The Rush coastal section}

The section is located south of and in Rush Harbour about $23 \mathrm{~km}$ north northeast of Dublin, at latitude 5331' $21^{\prime \prime} \mathrm{N}$ and longitude $6^{\circ} 04^{\prime} 44^{\prime \prime} \mathrm{W}$. Its statigraphy and sedimentology have been studied over a long period (Bábek et al. 


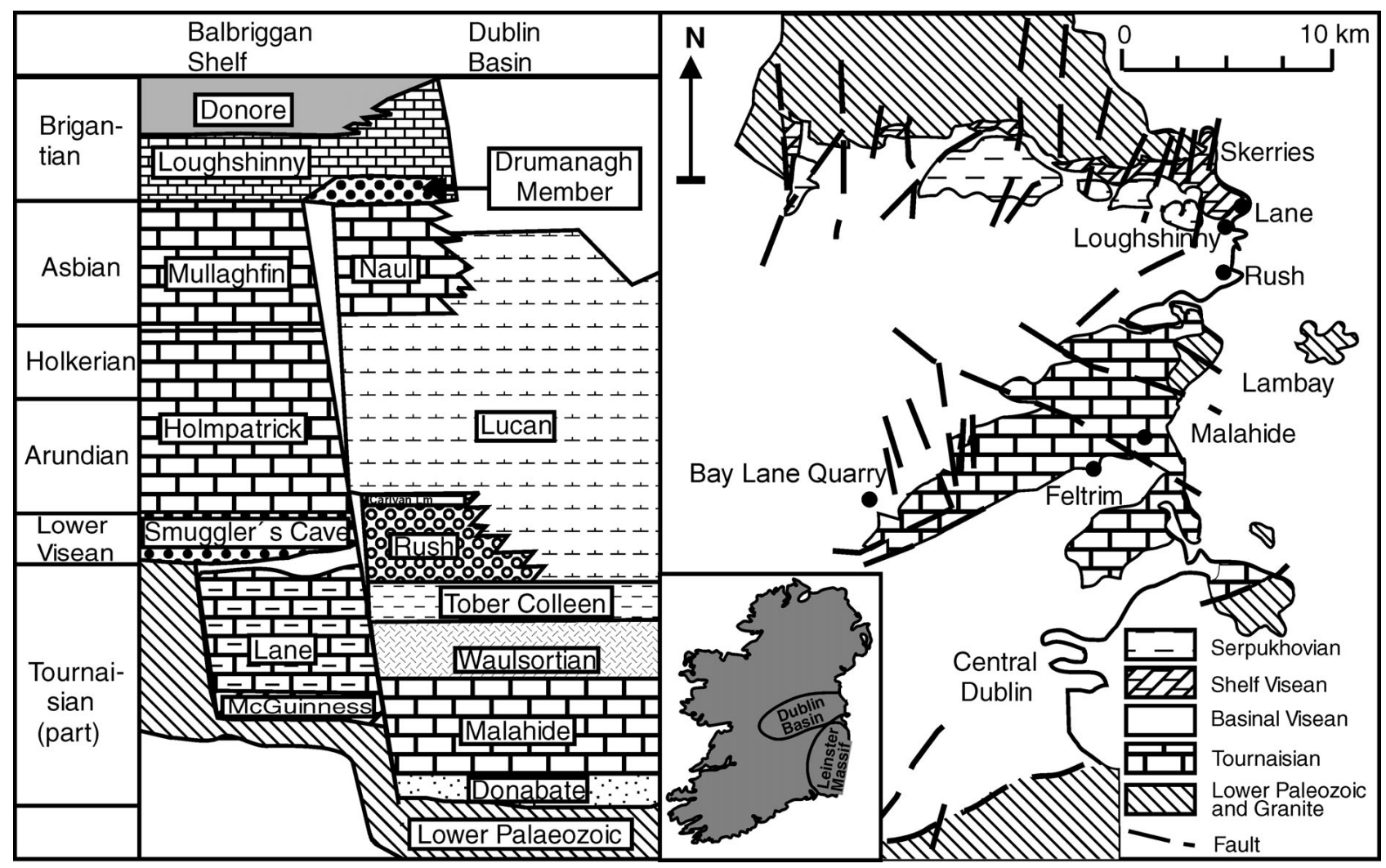

Figure 1. Location and lithostratigraphy of the Dublin Basin. Modified according to Sevastopulo \& Wyse-Jackson (2009).

2010; Devuyst 2006; Mamet 1969; Marchant 1978; Nolan 1986, 1989; Smyth 1951; these papers contain references to earlier literature). The Tober Colleen Formation, consisting of basinal calcareous mudrock with rare horizons of limestone, is inferred to overlie Waulsortian mudbank limestones and is overlain in turn by the Rush Formation (siliciclastic turbidites, calciturbidites and sediment flow deposits with appreciable terrigenous input from the east (Fig. 1) (Nolan 1986, 1989; Somerville et al. 1992a; Sevastopulo \& Wyse Jackson 2009). In this study the upper part of the Tober Colleen Fm. (56 m) and the of the Rush Formation $(136 \mathrm{~m})$ were logged lithologically and geophysically, and sampled for foraminiferans.

\section{The Bay Lane Quarry section}

Bay Lane Quarry is located $10.75 \mathrm{~km}$ northwest of Dublin, at latitude $53^{\circ} 35^{\prime} 21^{\prime \prime}$ and longitude $6^{\circ} 21^{\prime} 00^{\prime \prime}$. The succession has not been described before. Jones et al. (1988) in their regional map showed the position of the quarry in the outcrop belt of the Tober Colleen Formation; however, the lithologies in the quarry are much more quartz- and limestone-rich than those found in the type section of the Tober Colleen Formation at Rush and the biostratigraphy demonstrates that the Bay Lane succession is the age equi- valent of the Rush Formation and younger stratigraphical units. The succession in the quarry (over $125 \mathrm{~m}$ thick) is dominantly of tabular bedded, dark grey, sandy calcareous siltstone with several horizons of limestone containing conspicuous amounts of quartz sand. The rocks are interpreted here as being dominantly turbidites. There are very few benthic fossils but ammonoids occur at some horizons. Sole structures occur on the bases of many of the beds. The oldest $62 \mathrm{~m}$ present in the southeast corner of the quarry were stratigraphically and geophysically logged and sampled for microfossils.

\section{Material and methods}

Bed-by-bed logging with field description of bed thickness, bed geometry, grain size and sedimentary structures was performed on the Rush, Lane and Bay Lane Quarry sections.

The sections were also logged for GRS using an RS-230 Super Spec portable spectrometer with a $2 \times 2$ " $(103 \mathrm{ccm})$ bismuth-germanate (BGO) crystal detector (Radiation Solutions Inc., Canada). Counts per seconds in selected energy windows were directly converted to concentrations of $\mathrm{K}(\%), \mathrm{U}(\mathrm{ppm})$ and Th (ppm). Depending on the total thickness, the logging interval was 0.5 to $1.0 \mathrm{~m}$ 
(Rush), $0.5 \mathrm{~m}$ (Bay Lane Quarry) and $0.25 \mathrm{~m}$ (Lane). One measurement with a 240 -s count time was performed at each logging point, perpendicular to the section wall and at full contact with the rock. Detection limits are $0.1 \%$ for $\mathrm{K}$ and $0.4 \mathrm{ppm}$ for $\mathrm{U}$ and $\mathrm{Th}$. The combined error from operating conditions, instrument and repeated measurements was estimated to be less than about $\pm 7.5 \%$ for the K, U and Th concentrations. Four hundred and seventy four GRS data points (Rush: 288; Bay Lane: 123; Lane: 63) were measured in total.

Petrographic analysis was performed on a large number of standard size $(27 \times 46 \mathrm{~mm})$ thin sections $(200$ from Rush, 100 from the Bay Lane Quarry and more than 120 from the Lane section,) and two existing sets of thin sections from the thesis studies of T. Marchant and F.X. Devuyst. Semi-quantitative percentages of carbonate and non-carbonate constituents were recorded, using the visual comparison charts of Baccelle \& Bosellini (1965). Only allochems and detrital siliciclastic grains of the sand and gravel size fractions were considered. Results are presented as percentages of the total volume of the rock.

Foraminifers were studied with a high-magnification binocular microscope (Nikon 80i) in transmitted light at magnifications ranging from $20 \times$ to $400 \times$. The best specimens were photographed with a digital camera (Nikon DXM) and a database was created using Nikon NIS Elements software. High-resolution biostratigraphy of late Tournaisian and early Viséan is based on the foraminiferal zonation of Devuyst \& Hance (in Poty et al. 2006) which was subsequently refined by Devuyst (2006) and Devuyst \& Kalvoda (2007).

\section{Results}

\section{Facies and grain composition}

\section{Lane coastal section}

The measured section is $\sim 16.2 \mathrm{~m}$ thick (Figs 2, 5). A majority of the section comprises a succession of skeletal calcarenite beds with abundant large skeletal grains (nautiloids, gastropods, corals, brachiopods) alternating with thinner black mudstones (Lane Formation). The calcarenite beds are between $\sim 5$ to $\sim 50 \mathrm{~cm}$ thick, the mudstones up to $\sim 10 \mathrm{~cm}$ thick. Thickness of individual calcarenite beds is commonly very variable, with a tendency for lateral pinchouts. The calcarenite beds show common soft-sediment deformation, especially at their bases; they incorporate contorted mudstone laminae and lenses with frequent pinchouts; in some cases they are completely brecciated with the mudstone providing the matrix. Several beds are graded, and some also parallel-laminated. In the lower part of the section ( 12.5 to $\sim 14$ m below section top), the calcarenites contain abundant detrital quartz grains and/or layers and lenses of calcirudite rich in quartz pebbles. It is difficult to trace stratal patterns in the uppermost part of the Lane Formation (Fig. 5) and it is possible that this part is deformed by a fault with very limited displacement on the slip face. In the topmost part of the section, the calcarenite succession is overlain by several metres of clast-supported conglomerate (Smugglers Cave Fm.) with angular to subangular clasts of mainly low-grade metamorphic rocks and limestones of the Lane Formation. The basal contact of the conglomerate shows some undulation, which may be suggestive of erosion. This boundary is associated with paleokarst features according to Nolan (1986).

The carbonates can be classified as medium- to very coarse-grained, moderately to poorly sorted wacke-packstones, packstones, grainstones and rarely rudstones. Skeletal allochems (from 7.5 to $47.5 \%$ vol.) significantly predominate over non-skeletal ones (from 0 to $8.5 \%$ vol.) and detrital grains (from 0 to $31.5 \%$ vol.). Skeletal grains include abundant crinoids and other echinoderm fragments, plurilocular foraminifers, dasycladacean algae and bivalves, less abundant ostracods, bryozoans, brachiopods, gastropods, corals, calcispheres and rare spherical microproblematica, cyanophytes (Girvanella) and unidentified grains (Fig. 2). There is a weak trend of decreasing abundance of echinoderms and increasing abundance of peloids and dasycladacean algae in the upper part of the carbonate section, at $\sim 6 \mathrm{~m}$ below section top. The facies can be characterized as mixed heterozoan-photozoan foramderm (foraminiferal echinodermal) (James 1997, Halfar et al. 2004). Peloids and intraclasts strongly predominate over rare ooids among non-skeletal allochems. Detrital siliciclastic grains comprise angular to subrounded quartz grains, clasts of siltstones, chert and rare volcanic rocks. Generally, the rocks exhibit diagenetic features such as local dolomitization, rare silicification and micritization of skeletal grains. The stratigraphic distribution of the components is relatively uniform, with the exception of two important incursions of siliciclastic grains, one between $\sim 13$ and $\sim 16 \mathrm{~m}$, and the other between $\sim 6$ and $\sim 8 \mathrm{~m}$ below section top.

\section{Rush coastal section}

The basal part of the section (Fig. 6, 192 to $133 \mathrm{~m}$ below section top) comprises monotonous, dark-grey to black shales alternating with micritic argillaceous limestones with infrequent gastropods and nautiloids (Tober Colleen Formation; Nolan 1986, 1989). The overlying part (133 to $0 \mathrm{~m}$, Rush Formation) is composed of carbonate and siliciclastic-carbonate arenites alternating with shales, siltstones and siliciclastic-carbonate conglomerates and breccias (Bábek et al. 2010). The arenite beds are mediumto coarse-grained, typically $1 \mathrm{~cm}$ to $\sim 1 \mathrm{~m}$ thick, normally 


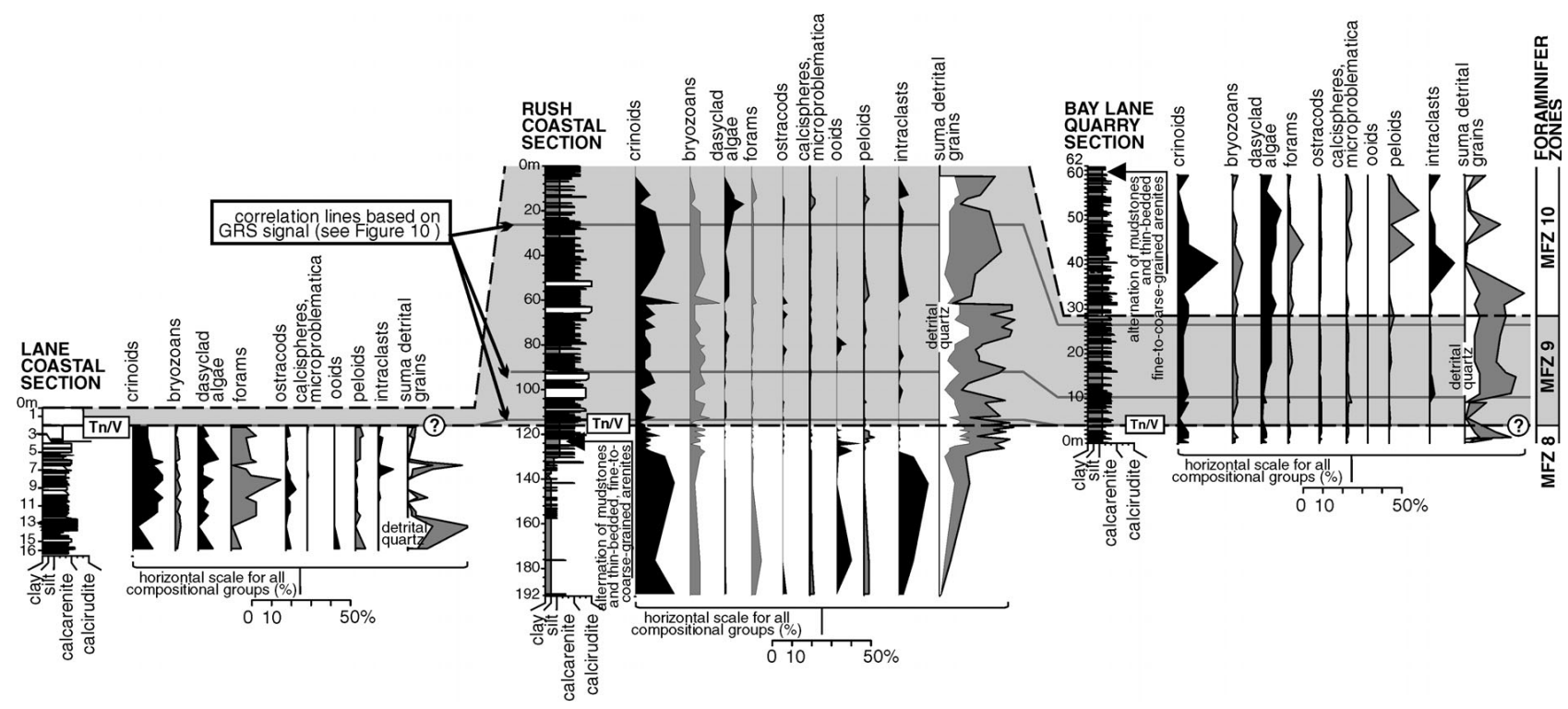

Figure 2. Stratigraphic trends in selected compositional groups (percentages from total rock volume based on visual estimates, using comparative charts) and correlation of the Lane (left), Rush (centre) and Bay Lane Quarry (right) sections based on Mississippian foraminiferal zones of Devuyst \& Hance (in Poty et al. 2006) (MFZ). The correlation is supported by correlation lines based on GRS logs, see text and Fig. 10.

graded, with sharp bases, parallel and wavy lamination, basal scours and shale lithoclasts. The conglomerates and breccias are up to $\sim 4 \mathrm{~m}$ thick, graded to non-graded, with outsized clasts, sometimes projecting above the bed tops, and are commonly associated with soft-sediment deformation beneath their bases. This succession is interpreted as carbonate and siliciclastic-carbonate turbidites and sandy debris-flow beds with the background sedimentation of hemipelagic clay-rich and silty sediments ( $c f$. Sevastopulo \& Wyse Jackson 2009). The Rush Formation starts with a thickening- and coarsening-upward (CU) succession (133 to $104 \mathrm{~m}$ ) of turbidites and sandy debris-flow beds, which is capped by two thick debris-flow breccias separated by coarse-grained and fine-grained turbidites (Fig. $6-$ 104 to $92 \mathrm{~m}$ ). These debris-flow beds are $\sim 3.5 \mathrm{~m}$ to $\sim 5 \mathrm{~m}$ thick, inversely and/or normally graded and capped with graded, coarse-grained calcarenites (turbidite cap). In the overlying succession (92 to $52 \mathrm{~m}$ ), shales and siltstones cyclically alternate with turbidites and debris-flow breccias with an overall 45 to 30 net-to-gross ratio. The top part of the section measured (52 to $5 \mathrm{~m}$ ), comprising a finingand thinning-upward succession of turbidites with upward-increasing proportion of shales ( 75 to 50 net-to-gross ratio at the top of this succession), is capped by thickbedded turbidites and sandy debris-flow deposits ( 5 to $0 \mathrm{~m}$; Bábek et al. 2010).

Under the microscope, the carbonates can be mostly classified as fine- to very coarse-grained, moderately sorted grainstones and packstone-grainstones with significant admixture of detrital, siliciclastic grains. Limestones of the Tober Colleen Formation are dominated by hetero- zoan carbonate skeletal allochems, in particular abundant crinoids, other echinoderm fragments and fenestrate bryozoans, less abundant foraminifers, sparse dasycladacean algae, ostracods, coral, brachiopod and bivalve fragments and rare sponge spicules, trilobites and conodonts (Fig. 2). Non-skeletal allochems, in particular intraclasts and rare ooids and peloids are less abundant (up to $17.5 \%$ ) than skeletal grains. Detrital siliciclastic grains are moderately abundant (up to 15\%). A marked compositional change can be traced near the base of the Rush Formation at $\sim 129 \mathrm{~m}$. The lower part of the Rush Formation, between $\sim 129$ and $\sim 60 \mathrm{~m}$, has significantly increased percentages of detrital siliciclastic grains (between 11 and $38 \%$ ), which include mono- and polycrystalline quartz grains, cherts, clasts of shales, siltstones, acid-intermediate volcanics and rare acid-intermediate plutonic rocks. Allochems are represented by similar groups as in the Tober Colleen Formation, but in lower percentages due to the dilution by detrital grains. The heterozoan-photozoan association of bioclasts is similar to the bryonoderm extended facies (Beauchamp 1994, Halfar et al. 2004, Kabanov 2009). The upper parts of the section, between $\sim 60$ and $0 \mathrm{~m}$, is characterized by slightly decreased percentages of detrital grains (between 6 and $31 \%$ ), slightly increased percentages of skeletal grains (mainly crinoids and bryozoans) and relatively high percentages of dasycladacean algae (more than 20\% of bioclasts - photozoan association of Halfar et al. 2004) together with peloids and intraclasts. Generally, the rocks exhibit common diagenetic alteration such as silicification, authigenesis (opaque minerals), endolithic borings and micritisation and sparse pressure dissolution. 


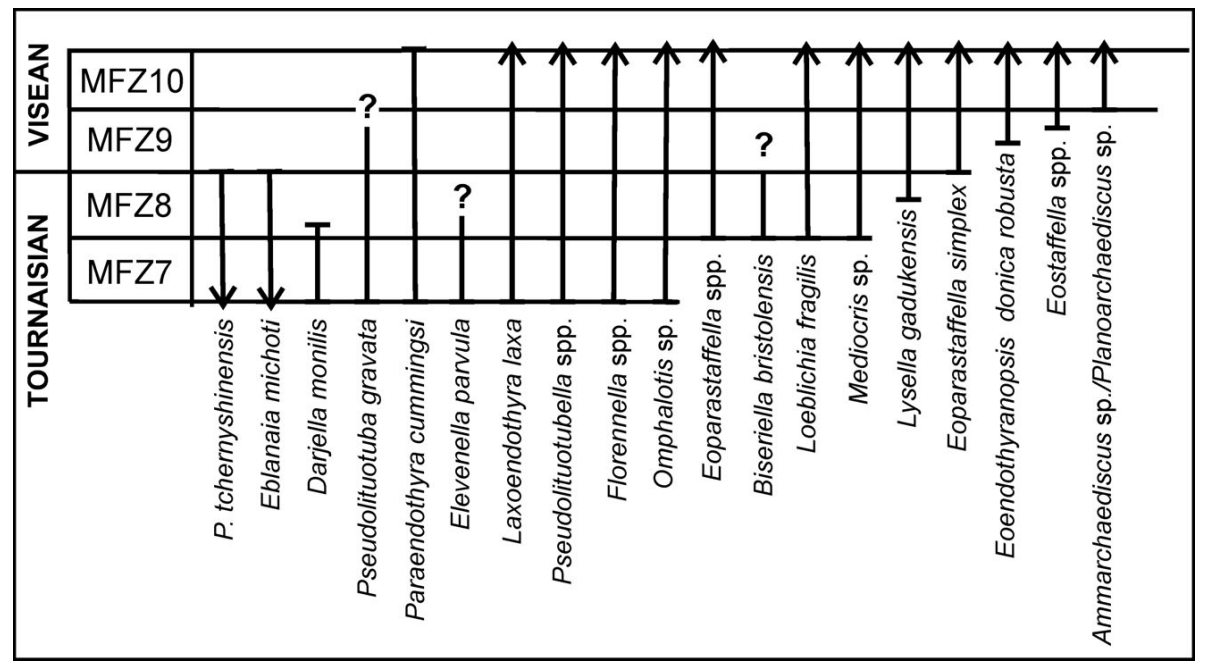

Figure 3. Foraminiferal zones of latest Tournaisian-earliest Viséan and ranges of important taxa. Modified according to Devuyst \& Hance (in Poty et al. 2006).

\section{Bay Lane Quarry section}

The measured section is $61.8 \mathrm{~m}$ thick and comprises a relatively monotonous succession of black mudstones alternating with beds of fine-to-coarse-grained, mixed carbonatesiliciclastic arenites (Figs 2, 7). The arenite beds are commonly graded, parallel-laminated, cross-laminated and/or ripple-cross-laminated and contain abundant erosive bases. Majority of the arenite beds can be interpreted as mixed carbonate-siliciclastic turbidites. Their thickness vary from $<0.5 \mathrm{~cm}$ to $\sim 60 \mathrm{~cm}$. Convolute bedding, soft-sediment deformation of the mudstones and arenite beds and load casts are present at some levels. Some beds are strongly calcareous and some contain calcareous nodules as large as $30 \mathrm{~cm}$. The basal part ( 0 to $1 \mathrm{~m}$ ) and top parts of the section (55 to $62 \mathrm{~m})$ are predominantly fine-grained. The intermediate strata are generally coarser-grained and thicker, but they fail to show clearly visible trends in bed thickness and/or grain size. Higher abundances of thicker and more coarse-grained beds are located between 1 and $3.5 \mathrm{~m}, 5$ and $11 \mathrm{~m}, 23$ and $27 \mathrm{~m}$, and 31 and $35 \mathrm{~m}$. Several levels at the section show tendency to high $\mathrm{CaCO}_{3}$ contents, indicated by frequent calcareous nodules and presence of strongly calcareous arenite beds, in particular between 5 and $12 \mathrm{~m}$, 23 and $26 \mathrm{~m}$, and 39 and $48 \mathrm{~m}$.

The mainly calciturbiditic carbonates can be mostly classified as fine- to medium-grained, moderately sorted wackestones and wacke-packstones, rarely grainstones, with significant admixture of detrital siliciclastic grains. Skeletal allochems (from 17.5 to $58 \%$ vol.) are most abundant, in particular crinoids and other echinoderm fragments, foraminifers, green algae (dasycladaceae), ostracods, calcispheres and spherical microproblematica, coral-, brachiopod-, fenestrate bryozoan-, trilobite- and bivalve fragments, sponge spicules and conodonts (Fig. 2). The association corresponds to the transitional heterozoan-photozoan association (Halfar et al. 2004). Radiolar- ians are abundant in several fine-grained wackestone beds. Non-skeletal allochems including intraclasts and peloids are much less abundant (up to 15\%) than skeletal grains; ooids are absent. Detrital siliciclastic grains are moderately abundant (up to $30 \%$ ) comprising mainly angular to subrounded quartz grains and clasts of siltstones, cherts and rare mudstones, and not very abundant K-feldspars, plagioclase feldspars, white micas and opaque grains.

Several not particularly distinct compositional trends can be traced up-section. The lower parts, between 0 and $\sim 15 \mathrm{~m}$, are predominantly fine-grained, with low percentages of allochems and detrital grains and, in places, high percentages of pelagic radiolarians (up to $15 \%$ ). Between $\sim 15 \mathrm{~m}$ and $\sim 40 \mathrm{~m}$ there is a strong siliciclastic admixture in the rocks (between 15 and 30\%) and the allochem composition is dominated by crinoids, bryozoans and increasing percentages of foraminifers and especially of dasycladacean algae. The facies corresponds to the photozoan association (James 1997, Halfar 2004). Between $40 \mathrm{~m}$ and the top of the measured section, the abundance of detrital grains is markedly reduced $(\sim 1$ to $\sim 17.5 \%)$ and there is a marked increase in peloids, calcispheres and spherical microproblematica, foraminifers and dasycladacean algae up-section, while the percentages of crinoids and bryozoans decrease. Generally, the rocks exhibit common diagenetic alteration such as silicification, authigenesis (opaque minerals) and rarely endolithic borings and micritisation.

\section{Biostratigraphy}

\section{Foraminiferal zonation}

The search for a new Tn-V boundary stratotype in Eurasia in the last decade has contributed to a substantial improvement in resolution of the biostratigraphical tools for identi- 


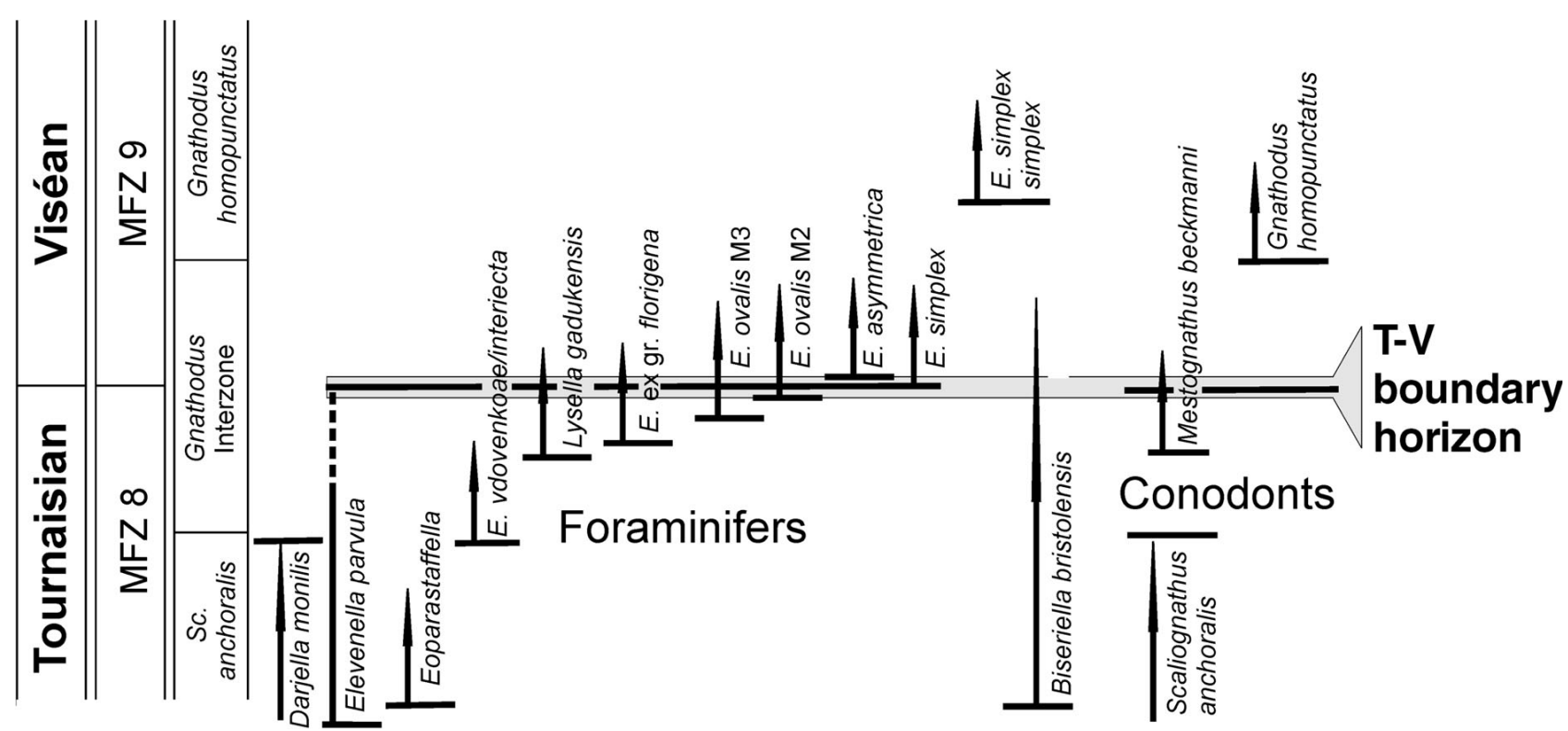

Figure 4. High resolution biostratigraphy of the Tournaisian/Viséan boundary interval. Based on Devuyst (2006).

fication of the Tournaisian-Viséan boundary interval. An example of this is the foraminiferal zonation of Devuyst \& Hance (in Poty et al. 2006) (Fig. 3), refined subsequently by Devuyst (2006) and Devuyst \& Kalvoda (2007). In this zonation, the Tn-V boundary can be identified using the boundary between MFZ 8 and 9. The base of MFZ 8 is characterized by the FADs of Eoparastaffella and Biseriella bristolensis (Reichel) and the base of MFZ 9 by the FAD of Eoparastaffella simplex Vdovenko. The entry of Eoparastaffella simplex is preceded by the successive FADs of Eoparastaffella vdovenkoae Devuyst \& Kalvoda, Lysella gadukensis Bozorgnia, Eoparastaffella ex gr. florigena (Pronina), Eoparastaffella ovalis Vdovenko M3, and Eoparastaffella ovalis M2, the latter just below the boundary. Eoparastaffella asymmetrica Vdovenko appears at or just above the boundary (Devuyst 2006) (Fig. 4). The entry of Eoparastaffella ovalis M2 is very close to the entry of E. simplex and because in many sections E. ovalis M2 is more common than E simplex, it can be used as an alternative criterion to identify the Tournaisian-Viséan boundary (Devuyst 2006, Kalvoda et al. 2010). It should also be mentioned that the LADs of Elevenella parvula (Bozorgnia) and Darjella monilis Malakhova in the upper part of MFZ 8 represent other important bioevents (Fig. 4) (Poty et al. 2006, Devuyst \& Kalvoda 2007, Kalvoda et al. 2010). Brenckle et al. (2009) recently showed that the range of $B i$ seriella bristolensis extends well into the Viséan in contrast to what is indicated in the zonation of Devuyst \& Hance (in Poty et al. 2006). This does not diminish the importance of its FAD for the base of MFZ 8.

Typical foraminifers from the Lane, Rush and Bay Lane Quarry section are illustrated in Figs 11-13.
Lane

The richest foraminiferal associations in this study have been encountered in the shallow water carbonate facies in the Lane section. This is consistent with the observation of Vdovenko (1980) that during the Carboniferous, calcareous foraminifers thrived mostly in shallow water infralittoral facies. However, the taxonomic diversity of the faunas at Lane is quite low. Revision of Marchant's $(1974,1978)$ samples and new sampling show that the upper part of the Lane Formation sampled in this study corresponds to the latest Tournaisian MFZ 8 of Devuyst \& Hance (in Poty et al. 2006) (Fig. 5). The presence of Darjella monilis (Malakhova) in the lower part of the section is typical of a late Tournaisian age (MFZ 7-8). The presence of Biseriella $\mathrm{cf}$. bristolensis and the record of B. bristolensis below the part of the section sampled in this study (Devuyst 2006) indicates MFZ 8 even in the lower part of the section. Eoparastaffella, the other guide for MFZ 8 is absent or rare which may reflect unfavourable facies.

The entry of Eoparastaffella ex gr. florigena and Eoparastaffella ovalis M3 in the very top of the section indicates the upper part of MFZ 8 and thus the proximity of the Tn-V boundary. This is in accordance with Marchant (1974) who illustrated Eoparastaffella ex gr. florigena, which he identified as E. simplex, from a clast in the overlying Smuggler's Cave Conglomerate.

The presence of the late Tournaisian guide Elevenella parvula (Bozorgnia) and the absence of Eoparastaffella simplex support a latest Tournaisian age despite the presence of species generally regarded as Viséan guides, such as Forschia parvula (Rauzer-Chernoussova), Forschia 


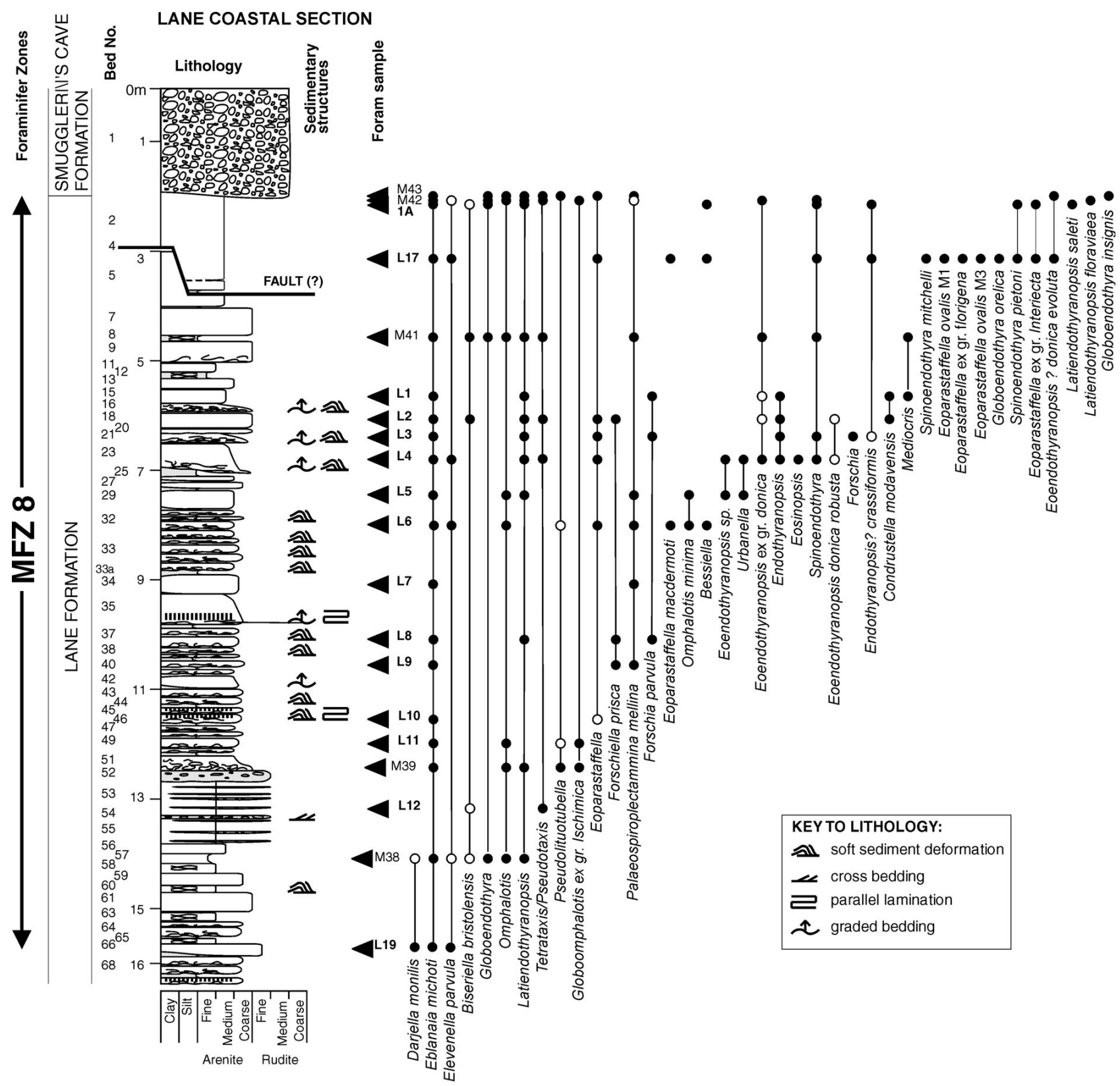

Figure 5. Distribution of most important foraminifers in the Lane coastal section. Foraminiferal zones according to Devuyst \& Hance in Poty et al. (2006). White circles mean $c f$. identifications. L - new samples, M - samples of Marchant (1978).

mikhailovi (Dain), Forschiella prisca (Mikhailov), Eoendothyranopsis? cf. donica robusta Conil and Eoendothyranopsis? donica evoluta Brazhnikova \& Rostovtseva (Brazhnikova \& Rostovtseva 1967; Vdovenko 1980; Devuyst \& Hance in Poty et al. 2006). It is noteworthy that the brachiopod Levitusia humerosus (Sowerby), now known to be restricted to the late Tournaisian in Belgium (Devuyst 2006), was recorded from the Lane Formation by Smyth (1949).

Most of the foraminiferal associations are dominated by Eblanaia spp. and other Tournayellidae (mostly
Endochernella and Spinochernella); more diversified associations occur only close to the top of the studied section. The impoverishment of the foraminiferal associations is most evident in the absence, or very rare occurrence of loeblichiids (absence of Dainella, Lysella, Florenella, rare occurrence of Spinoendothyra, Urbanella and Bessiella) and absence, or rare occurrence of Endospiroplectammina, Laxoendothyra laxa (Conil \& Lys), Brunsia, Mediocris and Plectogyranopsis which are all common taxa of the Late Tournaisian. Eblanaia is represented mostly by E. michoti (Conil \& Lys); however, as already stressed by 
Conil (1976), Eblanaia is characterized by considerable variability, both in terms of coiling and basal deposits and transitional forms to Globoendothyra occur. High equatorial and high oblique sections of Eblanaia are difficult do distinguish from Globoendothyra (Mamet et al. 1986). The Endothyranopsinae represent the second most common group and is represented mostly by Latiendothyranopsis spp. and less common Endothyranopsis and Globoendothyra spp. Globoendothyra spp. are not very common and are represented by specimens with a poorly differentiated wall (G. orelica Vdovenko) and specimens transitional between Globoendothyra and Omphalotis, which were included in the subgenus Globoomphalotis by Bogush (1987). Globoendothyra orelica with a poorly differentiated wall enters at Lane in the latest Tournaisian close to the $\mathrm{Tn}-\mathrm{V}$ boundary. These forms are common in the early Viséan of Ukraine (Brazhnikova \& Vdovenko 1973) and the Urals (Postoyalko 1975, Postoyalko \& Cherepanova 1990, Ivanova 2008, Stepanova et al. 2008) and in the early Viséan of the Namur Basin, Belgium (Conil et al. 1980). In eastern Europe the same is true for Globoendothyra insignis Postoyalko (Postoyalko 1975, Lyadova \& Pogorelov 1990). Globoomphalotis ishimica (Rauser) was originally described from the middle Viséan of Kazakhstan (Rauser 1948) but is more widely reported from younger parts of the Viséan (Visssarionova 1948, Brazhnikova \& Vdovenko 1973) of eastern Europe. However, specimens of G. ishimica characterized by a weakly differentiated wall similar to Eogloboendothyra have also been reported in the late Tournaisian-early Viséan interval in the Urals, Precaspian depression and Taymir (Malakhova 1975, Postoyalko 1975, Bogush 1987, Kulagina et al. 2003).

Eoendothyranopsis is quite rare and occurs only in the upper part of the section. In addition to Eoendothyranopsis? donica (Brazhnikova \& Rostovtseva) the entries of Eoendothyranopsis? donica evoluta and Eoendothyranopsis? cf. donica robusta are important. The first species is a guide of the foraminiferal zone Eoendothyranopsis donica-Omphalotis chariessa recognized in the early Viséan of eastern Europe (Vdovenko 1980) and the second and third species have been regarded as indicators of the Viséan (Vdovenko 1980; Devuyst \& Hance in Poty et al. 2006). However, the range of the species is not well established because Eoendothyranopsis? donica was recorded also below the $\mathrm{Tn}-\mathrm{V}$ boundary in Pengchong (Devuyst 2006).

\section{Rush}

Prior to the establishment of the GSSP for the base of the Viséan, the Tober Colleen Formation was regarded as being of early Viséan age, principally because the highest beds contain an ammonoid fauna that Smyth (1951) compared with faunas from supposedly Viséan levels in Germany. Mamet (1969) recorded faunas with archaediscids from the
Rush Formation, implying an Arundian age, but Marchant (1978) was unable to confirm these and identified the base of the Arundian in the uppermost part of the formation formerly referred to the Carlyan Limestone.

The upper part of the Tober Colleen Formation is charactarized by intercalations of biodetrital limestone beds with foraminifers within a background mudstone facies devoid of foraminifers. The foraminiferal associations of these limestone beds, as in the Lane Limestone Formation, are rich in the number of specimens but of low diversity. Eblanaia is the dominant genus acompanied by Globochernella, Spinochernella, Latiendothyranopsis, Globoomphalotis (G. ischimica) and Globoendothyra (G. insignis, G. ukrainica Vdovenko) and many of the late Tournaisian guides are missing (Fig. 6). This Eblanaia facies is also quite common in the pebbles and slumped beds of the Viséan Rush Formation. The facies control evidently also applies to the entry of Eoparastaffella. The first rare occurrences are recorded only in the uppermost part of the Tober Colleen Formation. However, the presence of advanced E. vdovenkoae in the lowest beds of the Rush Formation indicates already the upper part of MFZ 8 (Fig. 4) and suggests that the base of MFZ 8 is substantially lower than the entry of Eoparastaffella in bed R 88 (Fig. 6). This is consistent with the entry of Eoendothyranopsis? ex gr. donica in bed R 88 which indicates the proximity of the Tn-V boundary.

Occurences of foraminifers in the mixed carbonate-siliclastic sediments of the Rush Formation are rare due to the dilution by detrital grains and the specimens are commonly poorly preserved. Nevertheless, the associations are generally more diverse than in the Tober Colleen Formation. As already mentioned, the entry of E. vdovenkoae near the base of the formation indicates the upper part of MFZ 8. It is followed in close succession at Rush by the first E. ex gr. florigena, Eoendothyranopsis? donica evoluta Brazhnikova and Rostovtseva, and Lysella gadukensis indicating already the proximity of the $\mathrm{Tn}-\mathrm{V}$ boundary (Fig. 4). The presence of the MFZ 8 guide Elevenella parvula in the lower part of the Rush Formation, however, suggests still a Tournaisian age (Figs 3, 4). The next bioevent is the FAD of E. ovalis M2 which is regarded here as an indicator of the base of the Viséan (MFZ 9). The precise level of the entry of Eoparastaffella simplex is difficult to locate because of the rare occurrences and poor preservation of foraminifers. The first unambiguous Eoparastaffella simplex specimen represents already an advanced morphotype (Devuyst 2006). It is followed by E. asymmetrica Vdovenko \& Zavyalova, E. cf. restricta laciniosa Postoyalko, reported from the upper part of the lower Viséan in the Urals (Druzhinino Horizon; Postoyalko 1975), represents another indicator of a younger MFZ 9 association. The foraminiferal associations at the top of the studied section are poor containing typical representatives of MFZ 9 (Eoparastaffella simplex, 

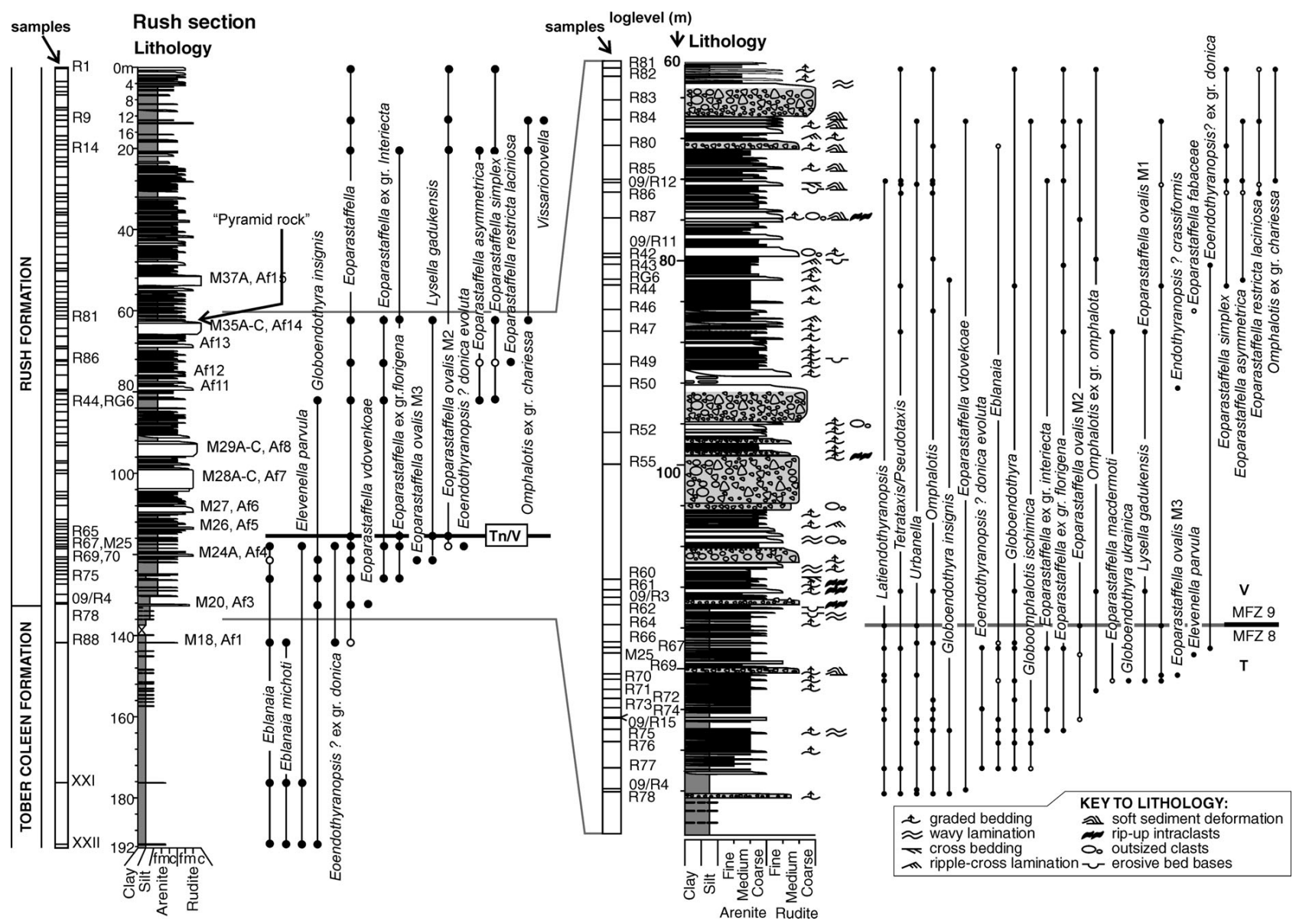

Figure 6. Distribution of most important foraminifers in the Rush section. Foraminiferal zones according to Devuyst \& Hance in Poty et al. (2006). White circles mean $c f$. identifications. R - new samples, M - samples of Marchant (1978), Af - beds of Afshar (1965).

Eoparastaffella ovalis M2, Vissarionovella sp. and lacking the archaediscid guides of MFZ 10 (Fig. 6). Archaediscids first occur in the highest part of the formation formerly referred to as the Carlyan Limestone (Fig. 1) separated from the studied section by the harbour.

\section{Bay Lane Quarry}

In the lower part of the studied section, the predominant facies consists of spiculitic limestones without or with rare foraminifers. In addition common diagenetic alteration makes taxonomic determinations difficult. The lowermost foraminiferal association (sample Q3) contains Eoparastaffella sp., Eoparastaffella ex gr. florigena and Lysella gadukensis indicating either uppermost MFZ 8 or MFZ 9 (Fig. 8). The second sample with a richer foraminiferal association occurs about $10 \mathrm{~m}$ higher (Q10) and contains in addition Eoendothyranopsis? cf. donica robusta. The first Eoparastaffella ovalis M2 occurs in sample Q13 and is followed by a more diverse association in Q14 with the first Eoparastaffella simplex, Eoparastaffella cf. restricta laciniosa, Omphalotis ex gr. chariesa (Conil \& Lys), and For- schiella prisca. This association resembles the association in sample R 86 at Rush and represents a level high in MFZ 9. The following interval with only an impoverished foraminiferal fauna is followed by a richer association in sample Q 17 with the first archaediscid (Glomodiscus sp., Uralodiscus sp.) which indicate a level above the base of MFZ 10 (see Fig. 2) (Devuyst \& Hance in Poty et al. 2006). Archaediscids occur only in one thin section and are absent above Q 17 up to the top of the measured section. The presence of Vissarionovella sp., Mediocris mediocris, Paralysella ex gr. schubertelloides (Bozorgnia), Nevillea sp., Lapparentidiscus bokanensis Vachard and transitional specimens between Eoparastaffella and Eostaffella characterizes the uppermost part of the measured section. Most probbaly the association still correspond to MFZ 10.

\section{Gamma-ray spectrometry}

Bivariate plots of $\mathrm{K}, \mathrm{U}$ and $\mathrm{Th}$ from all sections are shown in Fig. 8. The correlation between the total gamma-ray value (dose rate, $\mathrm{nGy} . \mathrm{kg}^{-1}$ ) and $\mathrm{K}$, Th and $\mathrm{U}$ concentrations 
BAY LANE QUARRY SECTION

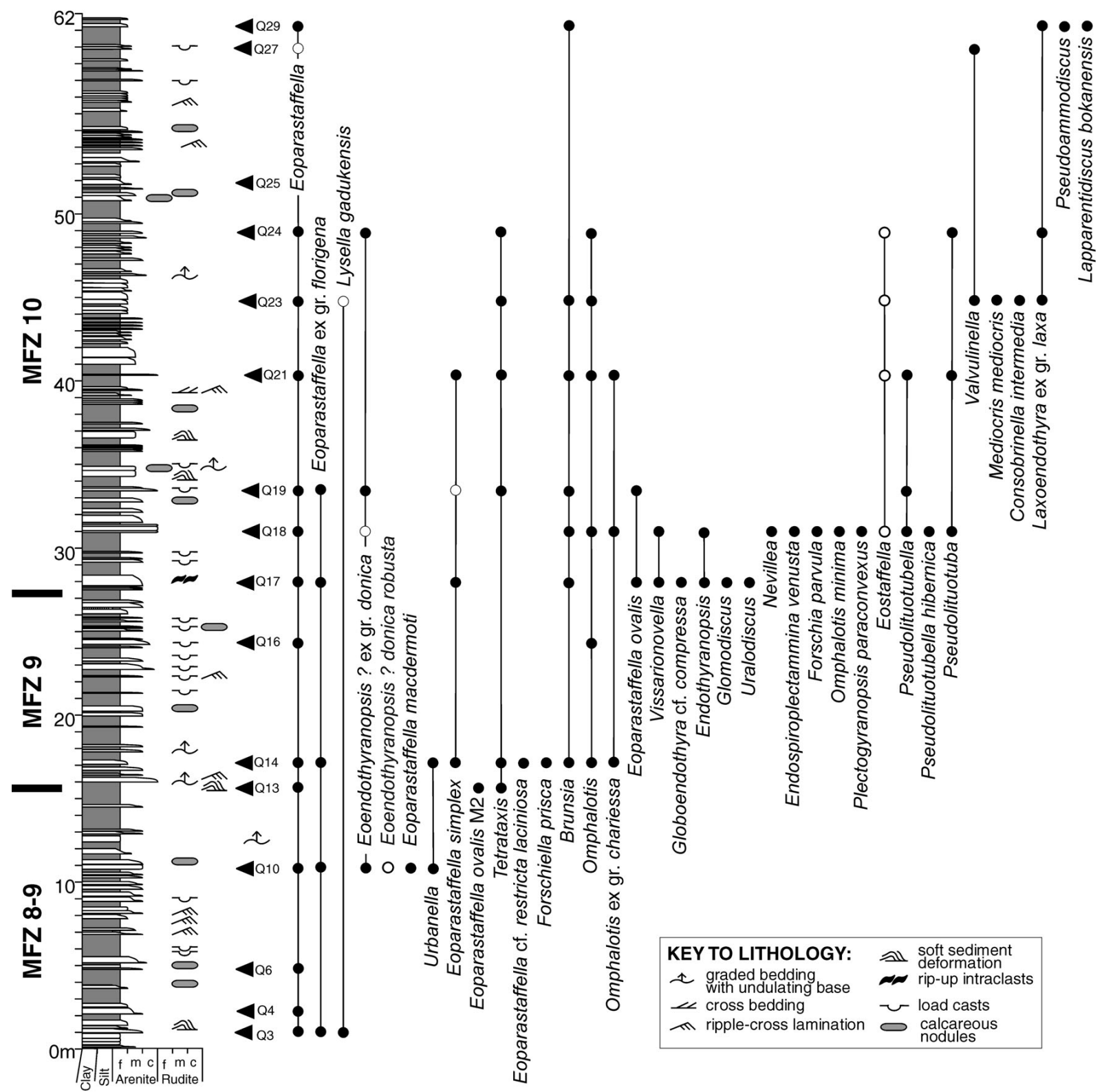

Figure 7. Distribution of most important foraminifers in the Bay Lane Quarry. Foraminiferal zones according to Devuyst \& Hance in Poty et al. (2006). White circles mean $c f$. identifications.

respectively, indicate that a major contribution to the total gamma-ray signal comes from K (linear regression coefficient; $\mathrm{R}^{2}=0.57$ for Lane, 0.92 for Rush, 0.79 for Bay Lane Quarry), followed by Th $\left(\mathrm{R}^{2}=0.51\right.$ for Lane, 0.51 for Rush, 0.82 for Bay Lane Quarry) and then $\mathrm{U}\left(\mathrm{R}^{2}=0.34\right.$ for Lane, 0.36 for Rush and 0.66 for Bay Lane Quarry). The K and Th concentrations show good correlation in Bay Lane Quarry and Rush (Fig. 8) and almost perfect correlation $\left(\mathrm{R}^{2}=0.96\right)$ in Lane. This indicates that the $\mathrm{K}$ and Th variation is driven by the dilution of $\mathrm{K}$ - and Th-bearing fine-grained siliciclastic components (illite and other clay minerals, micas, K-feldspars) in non-radioactive carbonate (Rider 1999, Doveton 1994, Fiet \& Gorin 2000, Ehrenberg \& Svana 2001, Fabricius et al. 2003, Bábek et al. 2007). This holds true, in particular, in the carbonate-dominated Lane section. In the Rush and Bay Lane Quarry sections, with high concentrations of siliciclastic detrital grains, the correlation is lower indicating that the GRS signal is influenced by additional variables such as the changing mineralogy of the detrital fraction (heavy minerals, micas, feldspars, etc.).

The GRS signal, in particular the $\mathrm{K}$ and Th concentrations, are strongly dependent on facies (Fig. 9) in all 

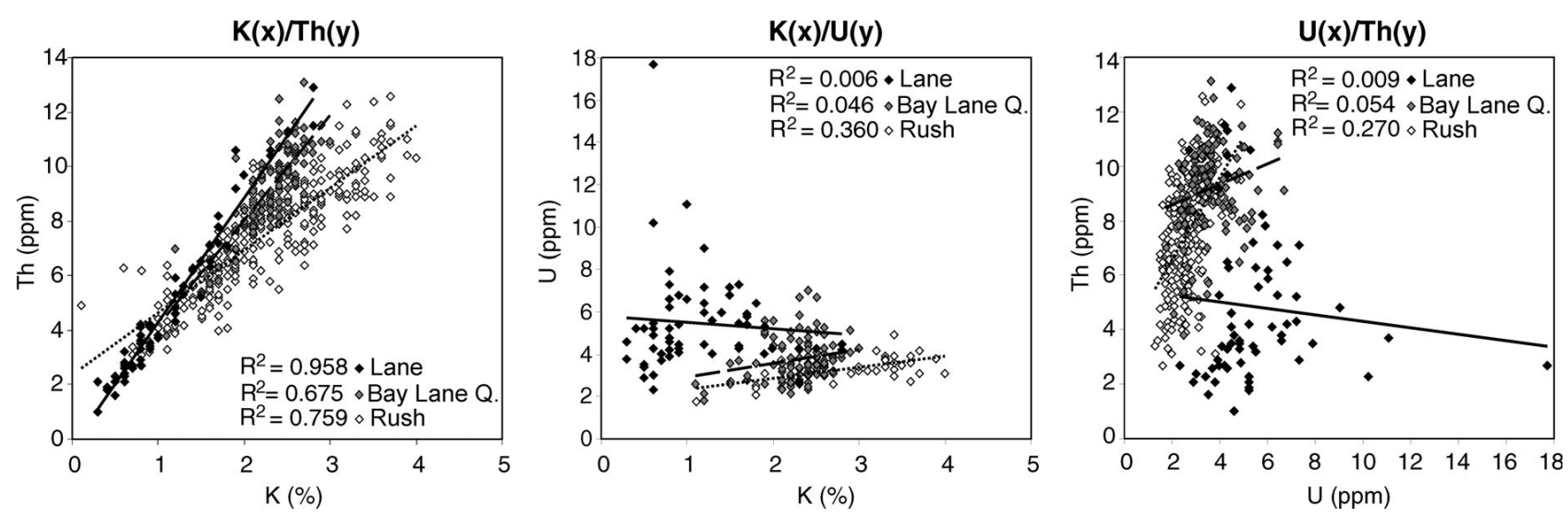

Figure 8. Bivariate plots and linear regression coefficients for K, Th and U concentrations at the Rush, Bay Lane Quarry and Lane sections. High linear regression coefficients in $\mathrm{K}$ : Th plots indicate the dilution effect of non-radioactive components (mainly carbonate) in radioactive components (mainly clay minerals).

sections. Relatively pure carbonates in the Lane section and thick carbonate breccias in Rush have low concentrations of $\mathrm{K}(\sim 0.6$ to $\sim 1.7 \%)$ and Th ( 2 to $\sim 7 \mathrm{ppm})$. Carbonates with siliciclastic admixture in the lower part of the Lane section have higher $\mathrm{K}(\sim 1$ to $\sim 2 \%)$ and Th $(\sim 5$ to $\sim 10 \mathrm{ppm}$ ) concentrations. Mixed carbonate-siliciclastic turbidites of the Bay Lane Quarry and Rush section have even higher $\mathrm{K}$ and Th concentrations (K: 1.5 to $\sim 3.2 \%$; Th: $\sim 7.5$ to $\sim 12 \mathrm{ppm}$ ), which are strongly proportional to decreasing grain size. The highest $\mathrm{K}$ and Th concentrations (K: $\sim 2.5$ to $3.8 \%$; Th: $\sim 8$ to $\sim 12 \mathrm{ppm}$ ) are attained in shales and fine-grained turbidites of the Rush and Bay Lane Quarry sections. Individual data points (layers) at the Bay Lane Quarry section have extremely high values of $\mathrm{K}$ and Th; these layers might represent tuff horizons (Fig. 9). Uranium has distribution, which is strongly dissimilar to Th and $\mathrm{K}$ and does not show the facies dependence. The $\mathrm{U}$ concentrations are relatively uniform in Rush and Bay Lane Quarry but there are strong peaks in the Lane section.

The GRS logs in the Lane section (Fig. 9) show a vertical organization, which is consistent with the lithology and component analysis. There is an increasing trend in concentrations of $\mathrm{K}$ and $\mathrm{Th}$ in the lower part of the section, between $\sim 16.5$ and $\sim 12.5 \mathrm{~m}$, which corresponds to the high contents of detrital grains (Fig. 9). Coinciding with low $\mathrm{U} / \mathrm{Th}$ ratios, the high $\mathrm{K}$ and Th concentrations suggest an increased influx of siliciclastics due to the proximity of land. A sudden drop of the $\mathrm{K}$ and Th contents at $\sim 12.5 \mathrm{~m}$, associated with the transition from mixed carbonatesiliciclastic deposits to pure carbonates, may therefore indicate a marine flooding surface. The overlying interval of relatively low concentrations of $\mathrm{K}$ and $\mathrm{Th}$ between $\sim 12.5$ and $\sim 5 \mathrm{~m}$ corresponds mainly to pure carbonate beds with shale interbeds, which indicate fully marine facies. Higher up in the carbonate succession, between $\sim 5$ and $\sim 2 \mathrm{~m}$, the $\mathrm{K}$ and Th contents tend to increase again. High uranium con- centrations in the shale interbeds between $\sim 6$ and $\sim 5 \mathrm{~m}$ coincide with moderate $\mathrm{K}$ and $\mathrm{Th}$ concentrations in a generally fine-grained carbonates facies with low detrital sandy admixture (Fig. 9). In contrast to thorium, which indicates terrestrial influence, uranium is usually assumed to indicate increased marine influence due to the presence of organic carbon and phosphate minerals (see below). The high $\mathrm{U} / \mathrm{Th}$ ratios in this interval may therefore indicate conditions of maximum flooding ( $c f$. Lüning et al. 2003, Doveton \& Merriam 2004, Halgedahl et al. 2009), which is supported by the relatively distal, fine-grained carbonate facies in the corresponding interval. The passage to the conglomerates of the Smuggler's Cave Formation at $\sim 2 \mathrm{~m}$ is associated with a sudden increase in $\mathrm{K}$ and Th concentrations and decrease in $\mathrm{U}$ concentrations and $\mathrm{U} / \mathrm{Th}$ ratios. This is assumed to reflect a sudden influx of terrigenous sedimentation (sea level lowstand conditions) as supported by the clast composition of the conglomerate. As suggested by the foraminiferal biostratigraphy, the base of the conglomerate may represent a boundary between the underlying, late Tournaisian marine carbonate sedimentation and the overlying, Viséan terrigenous sedimentation. However, the facies contrast and the $\mathrm{K}, \mathrm{U}$ and Th logs suggest the $\mathrm{Tn} / \mathrm{V}$ boundary might be associated with a hiatus.

In the Rush section (Fig. 9) the shales and limestones of the Tober Colleen Formation are characterized by moderately high concentrations of $\mathrm{K}$ and $\mathrm{Th}$, which show a cyclic arrangement and overall increase towards $\sim 156 \mathrm{~m}$ depth. The $\mathrm{K}$ and Th concentrations remain high up to the base of the Rush Formation at $\sim 133 \mathrm{~m}$ depth. Associated mainly with shales and distal, fine-grained turbidites, this peak GRS signal is suggestive of a maximum coastal shift of facies. The base of the Rush Formation is represented by a decreasing trend in the GRS signal ending up in a particularly low concentration of $\mathrm{K}$ and $\mathrm{Th}$ in the coarse-grained turbidites and carbonate debris-flow breccias between $\sim 92$ and $\sim 115 \mathrm{~m}$. The base of this interval $(\sim 116$ to $\sim 115 \mathrm{~m})$ 


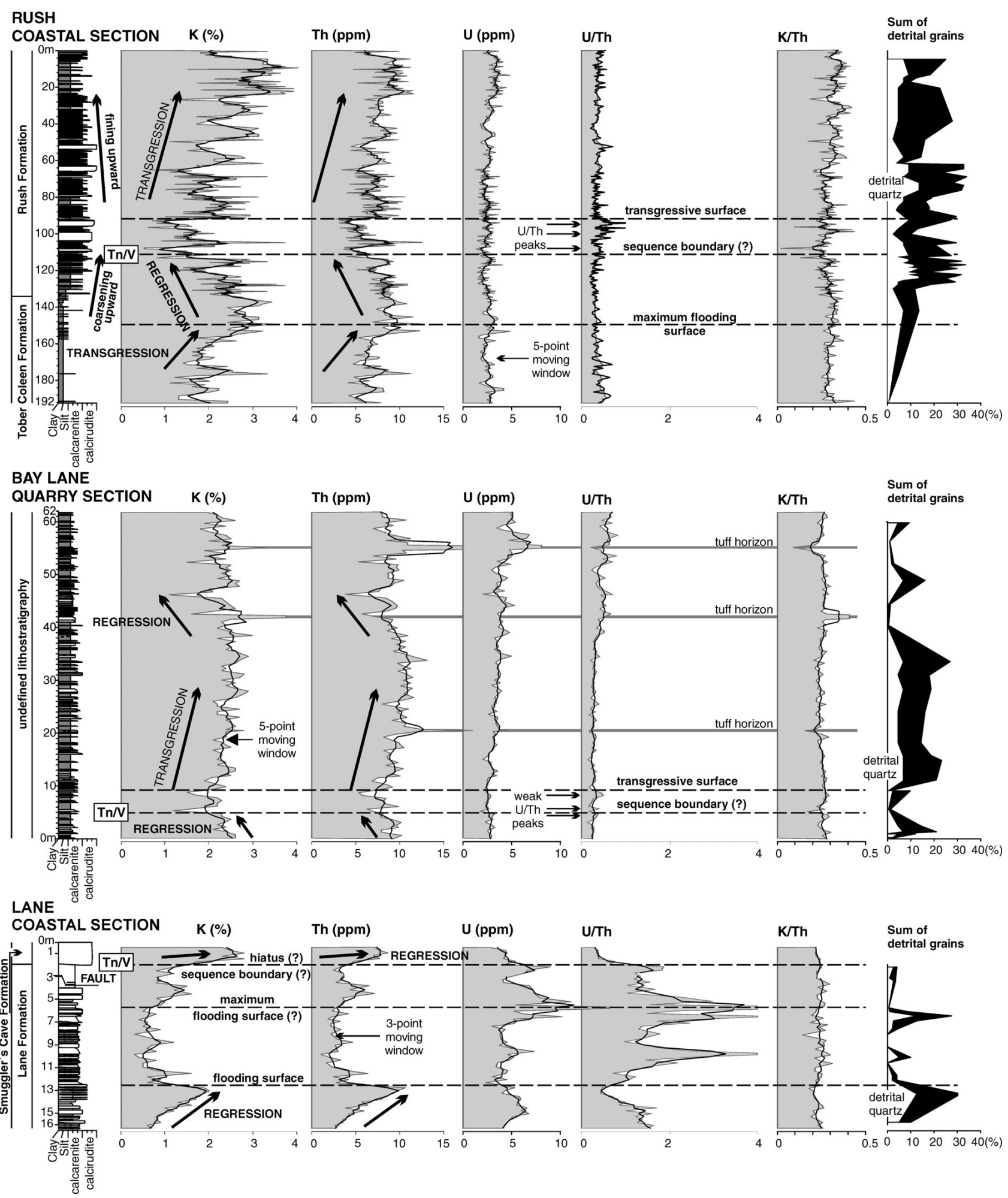

Figure 9. Lithology and spectral gamma-ray logs of the Rush (top), Bay Lane Quarry (centre) and Lane (bottom) sections with interpretation of important genetic surfaces and trends (arrows).

coincides with the first occurrence datums of the Viséan foraminifers (see section Rush above). These $\mathrm{K}$ and $\mathrm{Th}$ trends coincide with the CU trend in turbidite facies indi- cating overall progradation (regression?) of the turbidite system during a sea-level lowstand. An abrupt increase in $\mathrm{K}$ and Th concentrations at $92 \mathrm{~m}$ depth, associated with a 


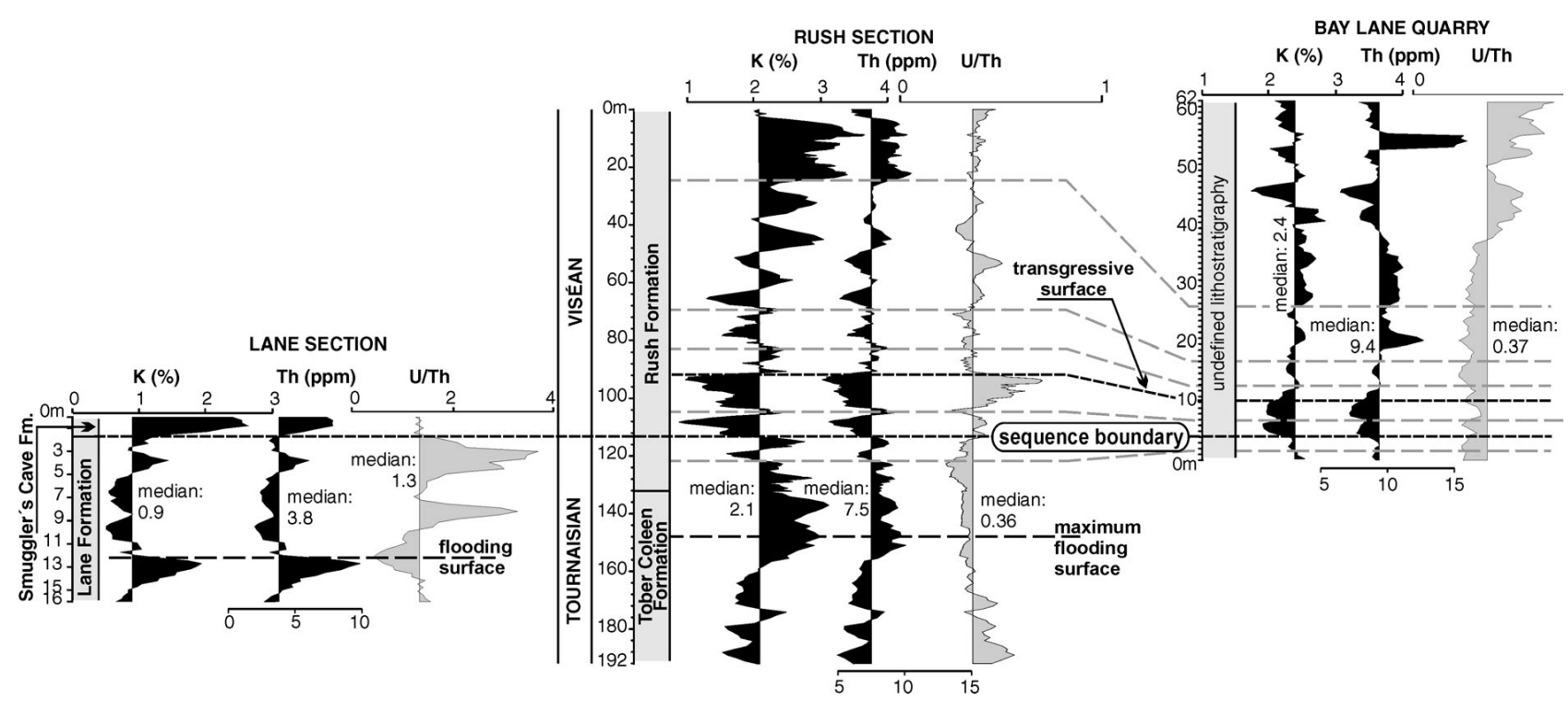

Figure 10. Geophysical correlation panel (K, Th and U/Th logs smoothed by 5-point moving window) of the Lane, Rush and Bay Lane Quarry sections with interpretation of important sequence-stratigraphic surfaces.

facies shift to a shale-rich interval, is suggestive of a transgressive surface (Fig. 9). This surface separates the K and $\mathrm{Th}$ logs into a lower, generally regressive section and an upper, generally transgressive section. The surface is followed by two $\mathrm{K}$ and Th cycles, which coincide with two $\mathrm{CU}$ facies trends ending up in debris-flow breccias, between 92 and $63 \mathrm{~m}$ and between 63 and $51 \mathrm{~m}$. Slightly higher U/Th ratios in the shaly interval at $\sim 81 \mathrm{~m}$ depth are suggestive of a local condensed horizon. Between $51 \mathrm{~m}$ and $24 \mathrm{~m}$ depth, the $\mathrm{K}$ and $\mathrm{Th}$ logs show increasing values, which are followed by maximum $\mathrm{K}$ and Th concentrations between $24 \mathrm{~m}$ and $4 \mathrm{~m}$. Since they are associated with a fining-upward facies trend, these log trends are suggestive of a major transgression followed by sea-level highstand conditions. In this interval, however, the Th and $\mathrm{K}$ logs reveal a hierarchic pattern with minor cycles superimposed on the major trends. Another major drop in $\mathrm{K}$ and Th concentrations occurs at $\sim 4 \mathrm{~m}$ depth indicating a regressive surface. The U/Th ratio is low ( 0.25 to 0.45$)$ throughout the Rush formation, apart from several minor peaks coinciding with low $\mathrm{K}$ and Th concentrations and carbonate-rich breccias where the U/Th ratio varies between 0.5 and 1 . In such examples, the higher U/Th ratios are assumed to indicate a carbonate-rich lithology rather than condensation.

The GRS logs in the Bay Lane Quarry (Fig. 9) show a certain degree of vertical organization. The most significant features include the low concentrations of $\mathrm{K}$ and $\mathrm{Th}$ at $\sim 5$ and $\sim 11 \mathrm{~m}$, which coincide with a local positive peak on the U/Th $\log$ and a set of relatively thick, strongly calcareous turbidite layers. This level is situated between foraminifer sample Q3, which may indicate the uppermost Tournaisian or the lowermost Viséan, and the Viséan foraminifer sample Q10 (see section Bay Lane Quarry above). Consequently, we tentatively correlate these GRS log patterns with similar log patterns in the Rush section located between $\sim 92$ and $\sim 115 \mathrm{~m}$, close to the Tn/V boundary (Figs 9, 10). Up-section, the concentrations of $\mathrm{K}$ and Th as well as the total GR signal increase reaching maxima between $\sim 26$ and $\sim 37 \mathrm{~m}$ and then decrease again to reach distinct minima in the strongly calcareous turbidites between $\sim 42$ and $\sim 47 \mathrm{~m}$. The increasing trend can be correlated with the log patterns between $\sim 92$ and $4 \mathrm{~m}$ in Rush and it is interpreted as a transgressive succession. There is another increase of $\mathrm{K}$ and $\mathrm{Th}$ concentrations in the upper part of the Bay Lane Quarry section, between $\sim 7$ and $61.8 \mathrm{~m}$, which may represent another transgressive-regressive cycle, or a part of it, in the higher part of MFZ 10. Uranium concentrations show dissimilar vertical distribution. There is a net increase in $\mathrm{U}$ concentrations throughout the section. Three outliers (Fig. 9) showing extremely high concentrations of Th (18.2 ppm at $20.5 \mathrm{~m}$ above the section base), $\mathrm{K}$ (4.9\% at $41.9 \mathrm{~m}$ ) and $\mathrm{U}$ and Th (10.5 and $36.8 \mathrm{ppm}$, respectively, at $54.9 \mathrm{~m}$ ) can be interpreted as volcaniclastic layers with variable geochemical composition. Such layers can be extremely thin and overlooked during facies logging.

\section{Discussion}

\section{Biostratigraphy and microfacies}

Among the three studied sections, the Tn-V boundary is best documented in Rush, where it falls in the lower part of the Rush Formation, as already suggested by Devuyst (2006). Ammonoids in Rush reported by Smyth (1951) correspond to Ammonellipsites-Fascipericyclus zone 

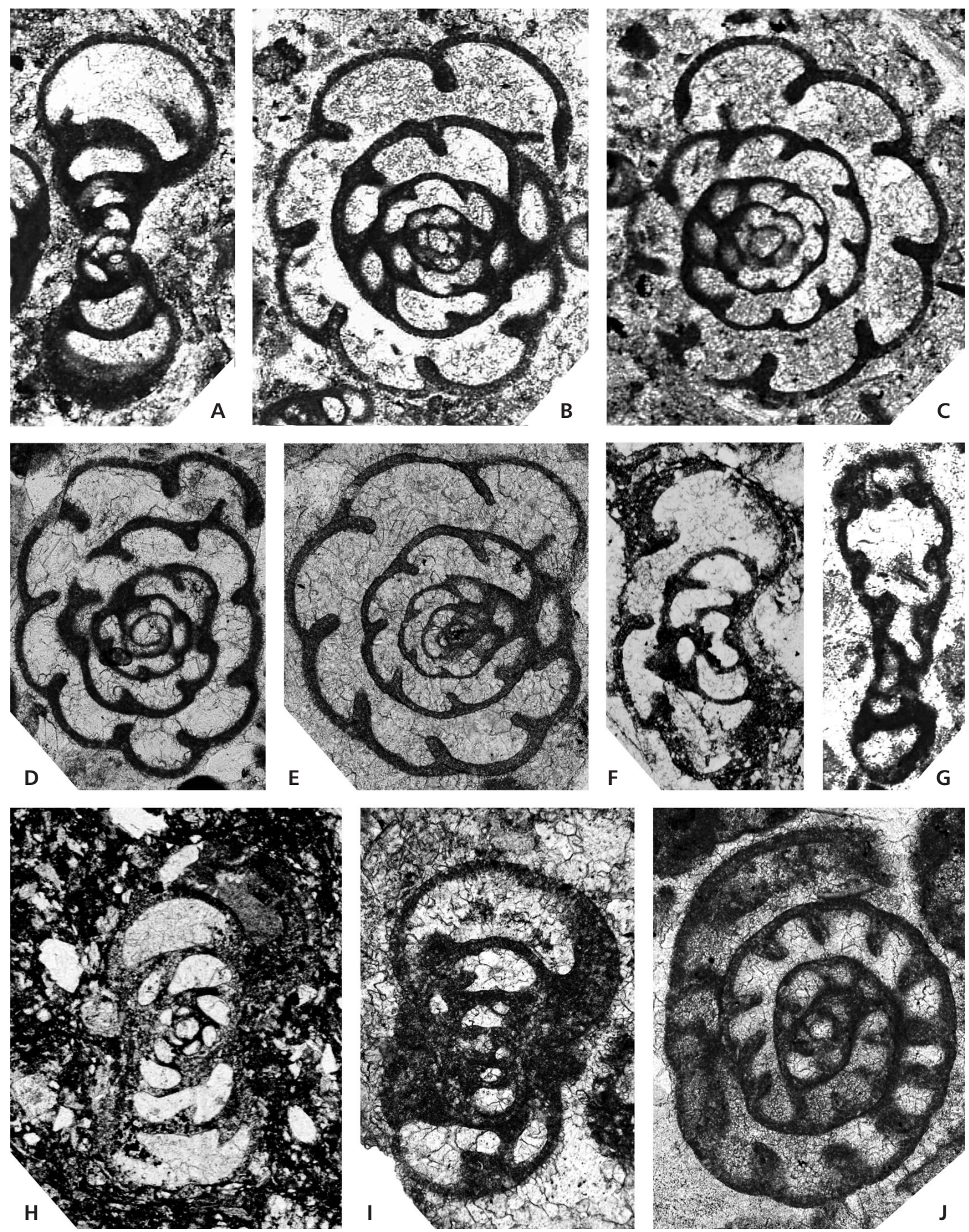

Figure 11. Typical foraminifers from Lane, Rush and Bay Lane Quarry sections. Foraminiferal zones MFZ according to Devuyst \& Hance (in Poty $e t$ al. 2006). A-F - Eblanaia michoti (Conil \& Lys), A - Lane L6, t.s. 1, MFZ 8, 50×, B - Lane L6, t.s. 2, MFZ 8, 50×, C - Lane L2, t.s. 2, MFZ 8, 50×, D - Lane L19, t.s. 1, MFZ 8, 50×, E - Lane L10, t.s.2, MFZ 8, 50×, F - Rush R88, t.s. 1, MFZ 8, 50x. $\bullet \mathrm{G}-$ Forschiella prisca Mikhailov, Lane L9, t.s. 1 , 50x; MFZ 8. $\bullet \mathrm{H}-$ Eoendothyranopsis? ex gr. donica Brazhnikova \& Rostovtseva, Bay Lane Quarry Q10, t.s. 3, MFZ 8-9, 50x. • I, J - Eosinopsis sp., I - Lane, T43, MFZ 8, 75x; J - Lane L4, t.s. 3, MFZ 8, 50x. 
which in the British Isles correlates with the early and late Chadian, i.e. both with the latest Tournaisian and earliest Viséan (Tilsey \& Korn 2009). The FAD of Eoparastaffella vdovenkoae at the very base of the Rush Fm. and the FAD of Lysella gadukensis and LAD of Elevenella parvula a bit higher suggests that the boundary between the Tober Colleen and Rush Formations is in the latest Tournaisian (upper part of MFZ 8 - see Fig. 4) and may correlate with the boundary between the Waterfall and Owenriff Members of the Oughterard Formation in western Ireland where Lysella gadukensis starts at the base of the Owenriff Member (Devuyst 2006). Both levels are characterized by an increase in moravamminids which may be connected with the reorganization from a ramp into platform - rimmed basin (Sommerville et al. 1992, Pickard et al. 1994, Strogen et al. 1996). In the Lane section, the Lane Formation corresponds to the latest Tournaisian MFZ 8 foraminifer zone and the top of the section correlates with the latest part of MFZ 8, as already stressed by Devuyst (2006).

In the Bay Lane Quarry section the oldest foraminiferal association in sample Q3 (Fig. 7) is not adequate for a conclusive date (MFZ 8-9), but both GRS logging and microfacies study suggest that the Tn- $\mathrm{V}$ boundary is present in the lowermost part of the section above this sample. In the middle of the measured section, Arundian strata was detected (Fig. 7). The entry of the first archaediscids in the Bay Lane Quarry indicates a level above the base of MFZ 10 (Fig. 2). A similar fauna was obtained from the Carlyan Limestone above the studied part of the Rush section (Marchant 1978). The base of the Arundian in the British Isles may be difficult to identify (Simpson \& Kalvoda 1987, Strogen et al. 1990) and additional criteria may be required. Similar problems with the entry of archaediscids above the probable base of the Arundian have been encountered in Belgium (Hance 1988) and in the Pengchong Tn-V boundary stratotype in southern China (Devuyst et al. 2003, Devuyst 2006). Up-section the increasing representation of dasycladaceans is apparent. The bioclast association in the calciturbidites corresponds to the heterozoan-photozoan facies in the lowermost part and to the photozoan facies in most of the section. This change in the upper part of MFZ 9 approximately $15 \mathrm{~m}$ from the base of the section may correlate with the similar change to photozoan associations in the higher part of MFZ 9 approximately $60 \mathrm{~m}$ below the top of the section in Rush and may be connected with the growth of the carbonate platform (Somerville et al. 1992a, Pickard et al. 1994, Strogen et al. 1996).

The late Tournaisian Eblanaia facies in Lane and Rush is associated with heterozoan-photozoan facies and closely resembles similar associations described by Devuyst (2006) in the Oughterard Formation in western Ireland. The impoverishment of the foraminiferal associations is most evident in the absence or very rare occurrence of loeblichiids and Eoparastaffella. The occurrence of the stratigraphical guides for the latest Tournaisian represented by species of Eoparastaffella, Lysella gadukensis, Elevenella parvula and Darjella monilis (Devuyst \& Kalvoda 2007) is facially controlled. The Lane section is a good example of a succession where the whole sequence corresponds to the MFZ 8 biozone but the most important guide of the zone, Eoparastaffella, is absent in the lower part of the section. A similar late entry of the first Eoparastaffella has been reported also in the Oughterard Formation in western Ireland (Devuyst 2006). Both in Lane and Rush, and in Oughterard the entry of Eoparastaffella is connected with the transition from heterozoan carbonates to more diversified heterozoan-photozoan facies.

On the other hand the study of the Irish sections shows that some species that have generally been regarded as Viséan guides in eastern Europe, such as Forschia parvula, Forschia mikhailovi, Forschiella prisca, and Eoendothyranopsis? donica evoluta, Eoendothyranopsis? donica donica (Vdovenko 1980, Postoyalko 1975) first occurred in the Tournaisian. A possible explanation for this may be the absence of detailed bed-by-bed studies in Russia and Ukraine.

Further progress in high resolution foraminifer biostratigraphy of the Early Carboniferous will have to take into account the ecology of foraminifers (especially depth stratification and interplay between nutrients and oxygen levels) and the depositional features of limestones (especially granulometric sorting). Although this is beyond the scope of the present paper, it is worth mentioning that the low diversity foraminiferal fauna lacking some foraminiferal guides and containing abundant and morphologically diverse Eblanaia and other Tournayellidae that characterize the latest Tournaisian occurs in Lane in shallow water heterozoan-photozoan (foramderm) carbonates of the Lane Formation (Strogen et al. 1996). A similar association (bryonoderm extended) (Beauchamp 1994, James

Figure 12. Typical foraminifers from Lane, Rush and Bay Lane Quarry sections. Foraminiferal zones MFZ according to Devuyst \& Hance (in Poty et al. 2006). A - Eoparastaffella aff. restricta laciniosa Postoyalko, Bay Lane Quarry, Q14, t.s. 2, MFZ 9, 75×. B - Eoparastaffella macdermoti Devuyst \& Kalvoda, Rush R86, t.s. 1, MFZ 9, 75×. • C - Eoparastaffella cf. macdermoti Devuyst \& Kalvoda, Lane L17, t.s. 2, MFZ 8, 75×. • D - Eoparastaffella sp., Rush R14, t.s. 4, MFZ 9, 75×. • E, I, P, S - Eoparastaffella ex gr. florigena (Pronina), E - Lane L17, t.s. 4, MFZ 8, 75×, I - Rush RG6a, MFZ 9, 75×, P - Rush R14, t.s. 4, MFZ 9, 75×, S - Rush R14, t.s. 3, MFZ 9, 75×. • F - Eoparastaffella ex. gr. asymmetrica Vdovenko \& Zavyalova, Rush RG6b, MFZ 9, 75×. $\bullet \mathrm{G}, \mathrm{H}-$ Eoparastaffella macdermoti Devuyst \& Kalvoda, juvenile or E. ovalis Vdovenko M1, G - Lane L17, t.s. 1, MFZ 8, 75×, H - Rush R47, t.s. 3, MFZ 9, 75×. - J - Eoendothyranopsis? donica evoluta Brazhnikova \& Rostovtseva, Lane 41, TCD 18331, MFZ 8, 75×. • K - Eoparastaffella simplex Vdovenko, Rush R85, t.s. 2, MFZ 9, 75×. - L - Eoparastaffella cf. vdovenkoae Devuyst \& Kalvoda, juvenile, Lane L17, t.s. 3, MFZ 8, 75×. 

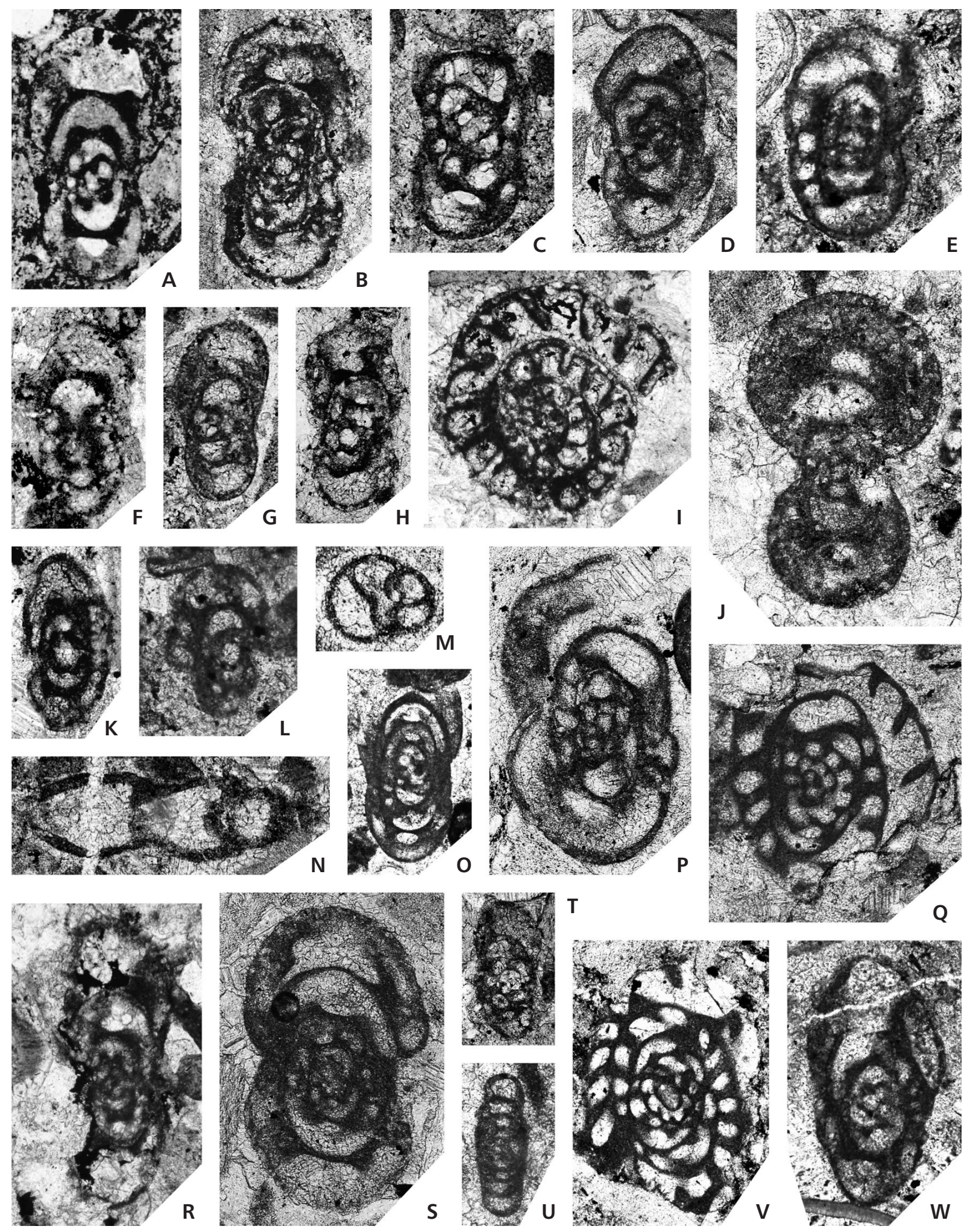

- M - Biseriella bristolensis (Reichel), Lane 31, TCD 12382, MFZ 8, 100x. - N - Elevenella parvula (Bozorgnia), Rush R89, t.s. 3, MFZ 8, 75x. - O - Paralysella schubertelloides (Bozorgnia), Bay Lane Quarry Q23, t.s. 4, MFZ 10, 75x.・Q, V - Vissarionovella sp., Q - Rush R9, t.s. 1, MFZ 9, 75×, V - Bay Lane Quarry Q18, t.s. 4, MFZ 10, 75x. $\bullet$ R - Eoparastaffella cf. restricta Postojalko \& Garan, Rush RG9a, MFZ 9, 75x. $・$ T - Eoparastaffella ovalis Vdovenko, M2, Rush Marchant's sample 25, MFZ 9, 75×. U - Lapparentidiscus bokanensis Vachard, Bay Lane Quarry Q29, t.s. 5, MFZ 10, 100x.・W - Eoparastaffella simplex Vdovenko (transitional to Eostaffella), Bay Lane Quarry, Q21, t.s. 1, MFZ 10, 75x. 
1997) was encountered in calciturbidites of the Tober Colleen Formation at Rush. Heterozoan-photozoan associations in shallow water tropical belts commonly indicate cold water upwelling (Carannante et al. 1988, Schlager 2003, Westphal et al. 2010). Similar associations in shallow water tropical carbonates were decribed by Brandley \& Krause (1997) from the early Carboniferous formations of the Rundle Group (especially the Turner Valley Formation) in western Canada which are also dominated by Eblanaia and other tournayellids (Beauchamp \& Mamet 1985, Mamet et al.,1986). Generally Eblanaia is common in late Tournaisian and earliest Viséan in the North American Cordillera where also the widespread species Septabrunsiina parakrainica Skipp (Sando et al. 1969, Beauchamp \& Mamet 1985) can be included in the genus (Conil \& Lys 1977, Brenckle 1997).

Upwelling and high nutrient levels strongly influenced Early Carboniferous low-latitude shallow seas of Laurussia (Wright 1994) and a wide belt of oceanic upwelling has been postulated to have been active along the southern margin of western Laurussia (Wright \& Faulkner 1990; Wright, 1991, 1994; Bridges et al. 1995; Pickard 1996; Stanton 2006). The dominance of Eblanaia and other tournayellids in the North American Cordillera can be attributed to this upwelling and compared with buliminid dominance in foraminiferal associations in the Cretaceous or Paleocene upwelling belt of southern Tethys (Guasti et al. 2005, Aschkenazi et al. 2010). It remains to be clarified whether similar foraminiferal associations in Ireland can be attributed also to the upwelling hypothesized in the early Carboniferous of the British Isles (Wright 1991) or to an alternative explanations of higher trophic levels. The may be linkked also to the increased humidity in the late Tournaisian of the British Isles followed by the change to semi-arid conditions close to the $\mathrm{T}-\mathrm{V}$ boundary (Wright 1990). Whatever the reason may be, an important role played the transition from ramp sedimentation with high rates of heterotroph sediment production in mid-ramp settings in late Tournaisian to platform sedimentation in Viséan when the narrow belt of the photozoan carbonate factory with fusulinids widened (Somerville et al. 1992, Pedley 1998, Schlager 2003, Wright \& Burgess 2005).

\section{Gamma-ray log correlation and sequence stratigraphic interpretation}

Our analysis of the GRS signal and correlation with the facies logs suggest that the $\mathrm{K}$ and Th concentrations may serve as a proxy for overall landward / basinward facies shifts and as a proxy of $\mathrm{CaCO}_{3}$ contents in mixed carbonate-siliciclastic facies. Both can be linked to relative sea-level changes. The geophysical response of carbonate systems to transgressions and normal/forced regressions may vary significantly depending on platform morphology and position on platform-to-basin transect. Regressions in updip areas of carbonate systems result in decelerated/ceased carbonate production and increased aeolian/fluvial influx of siliciclastic material, which causes positive excursions on gamma-ray logs ( $c f$. Hladil et al. 2006). In downdip areas of carbonate ramps, a regression implies basinward shift of the carbonate factory (Wright 1986), which is associated with increased carbonate supply into the basin and negative excursions on gamma-ray logs (Koptíková et al. 2010). Transgressions and marine flooding imply opposite trends on geophysical logs. In extreme situations, minimum carbonate production in downdip areas of carbonate ramps and mixed carbonate-siliciclastic systems is attained during maximum flooding, which is associated with maximum gamma-ray values (Halgedahl et al. 2009). The response may differ significantly on slopes of rimmed carbonate shelves and flat-topped carbonate platforms, such as the Cainozoic Bahamas, which have tendency to maximum supply of carbonate into the basin during highstands (highstand shedding; Droxler \& Schlager 1985, Westphal et al. 2010). Concentrations of uranium in GRS logs are usually interpreted as relating to the presence of organic carbon and calcium phosphates, which may indicate dysoxic/anoxic conditions and low carbonate productivity (Rider 1999, Ehrenberg et al. 2008). Intervals with high U/Th ratios are therefore in some cases interpreted as maximum flooding surfaces ( $c f$. Lüning et al. 2003, Doveton \& Merriam 2004, Halgedahl et al. 2009).

The three sections studied show correlatable patterns on the GRS logs, which are in line with the scenarios on mixed carbonate-siliciclastic systems. The $\mathrm{K}$ and Th concentrations and $\mathrm{U} / \mathrm{Th}$ and $\mathrm{K} / \mathrm{Th}$ ratios close to the biostratigraphic $\mathrm{Tn} / \mathrm{V}$ boundary are correlatable between Rush and Bay Lane Quarry sections (Fig. 10). There is a distinct drop in the $\mathrm{K}$ and $\mathrm{Th}$ concentrations, accompanied with a slight increase in the U/Th ratios near the FAD of the basal Viséan index foraminifer taxa (112 to $96 \mathrm{~m}$ in Rush; 5 to $11 \mathrm{~m}$ in Bay Lane Quarry). This interval coincides with the carbonate intraclast-rich, mass-flow breccias at the Rush section and carbonate-rich turbidites in the Bay Lane Quarry. The mass wasting associated with basinward shift of facies inferred from negative $\mathrm{K}$ and $\mathrm{Th}$ excursions can be interpreted as a result of destruction of the carbonate platform slope during relative sea-level fall (forced regression; cf. Sarg 1988, Coe 2003). This interpretation is supported by the regionally recognised forced regression / sea-level fall, which is associated with very rapid shallowing, exposure features and karstic surfaces in shallow-water $\mathrm{Tn} / \mathrm{V}$ boundary sections around the LondonBrabant Massif (Faulkner et al. 1990, Hance et al. 2001, Devuyst 2006).

Below the $\mathrm{Tn} / \mathrm{V}$ boundary interval, the $\mathrm{K}$ and Th concentrations tend to decrease ( 152 to $112 \mathrm{~m}$ in Rush; 0 to $5 \mathrm{~m}$ 

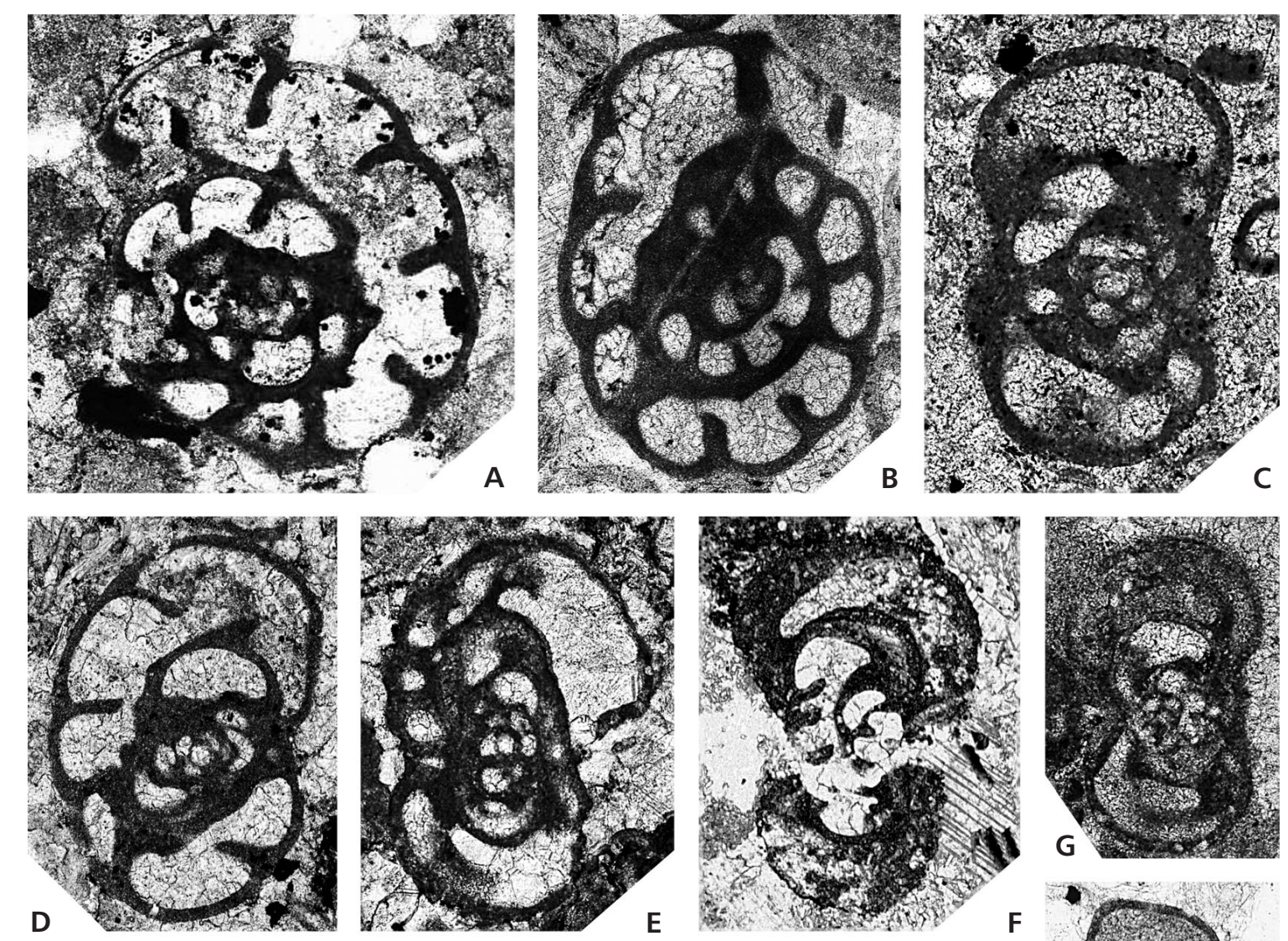
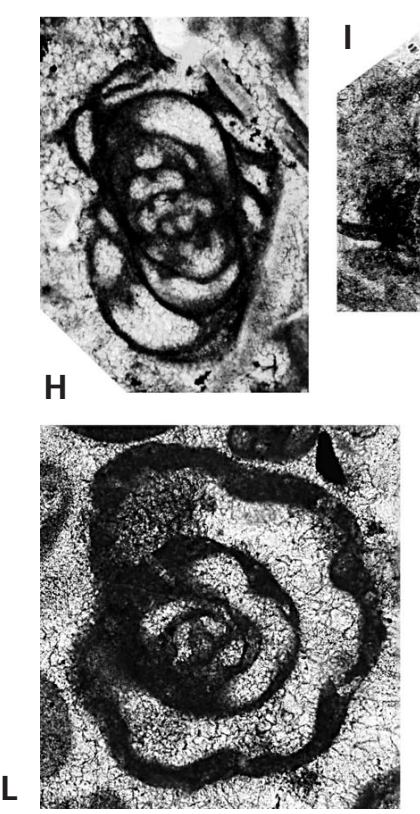
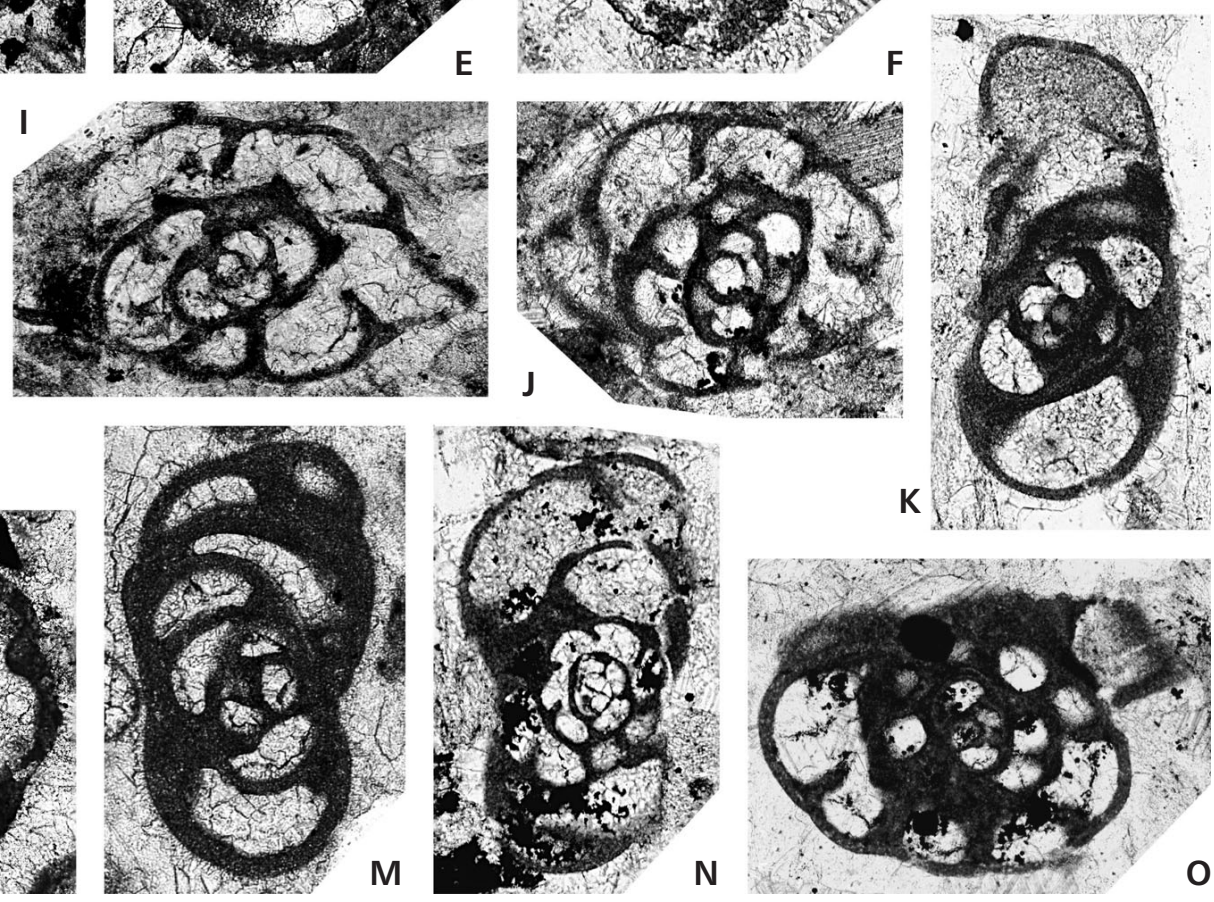

Figure 13. Typical foraminifers from Lane, Rush and Bay Lane Quarry sections. Foraminiferal zones MFZ according to Devuyst \& Hance (in Poty et al. 2006). A, K - Omphalotis ex gr. chariessa (Conil \& Lys), A - Bay Lane Quarry, Q 18, MFZ 10, t.s. 1, 75×, K - Rush, R75, t.s. 2, MFZ8, 75×. - B - Omphalotis omphalota (Rauzer-Chernousova \& Reitlinger), Rush R14, t.s. 5, MFZ9, 75x. $・$ C - Latiendothyranopsis sp., Lane L1A, t.s. 4, MFZ 8 , 75x.・D - Globoomphalotis sp., Bay Lane Quarry, Q 21, t.s. 6, MFZ 10, 75x. E - Eoendothyranopsis? cf. robusta (Conil \& Lys), Lane L4, t.s. 2, MFZ 8, 50x. $• \mathrm{~F}$ - Eoendothyranopsis? ex gr. donica Brazhnikova \& Rostovtseva, Rush R77, t.s. 6, MFZ 8, 50x. $\bullet \mathrm{G}-$ Eoendothyranopsis? donica evoluta (Brazhnikova \& Rostovtseva), Rush, 09/R13, t.s. 6, MFZ 9, 75x.・H - Lysella gadukensis Bozorgnia, Rush, R81, t.s. 3, MFZ 9, 75×. ・ I, J - Spinochernella brencklei Conil \& Lys, Rush, R89B, t.s. 3, MFZ 8, 75x. $\bullet$ L - Bogushella sp., Lane L1, t.s. 4, MFZ 8, 75x. • M - Globoomphalotis ischimica (Rauser), Lane, M39, MFZ 8, 75x. $・ \mathrm{~N}-$ Globoendothyra cf. insignis Postoyalko, Rush, R73, t.s. 2, MFZ 8, 75x. $\bullet$ - Omphalotis ex gr. omphalota (Rauzer-Chernousova \& Reitlinger), Rush R71, t.s. 4, MFZ 8,75x. 
in Bay Lane Quarry) while above it they tend to increase (96 to $6 \mathrm{~m}$ in Rush; 11 to $35 \mathrm{~m}$ in Bay Lane Quarry) indicating increasing and decreasing $\mathrm{CaCO}_{3}$ contents, respectively (Figs 9, 10). The upper Tournaisian K and Th trends correlate with the coarsening-upward succession in Rush, which indicates normal regression during late sea-level highstand or, more probably, forced regression (falling-stage systems tract), which is supported by the sudden influx of detrital grains slightly before the biostratigraphic Tn/V boundary. At the Bay Lane section only the uppermost part of the decreasing $\mathrm{K}$ and $\mathrm{Th}$ trends is exposed.

The lower Viséan increasing $\mathrm{K}$ and Th concentrations coincide with fining-upward successions, mainly in Rush but partly also in Bay Lane Quarry section, indicating deepening of the depositional setting (transgression). This is consistent with the early Viséan deepening-upward trend in shallow-marine carbonates at the Oughterard section, western Ireland (although this part of the Oughterard section may be affected by local synsedimentary tectonics) (Devuyst 2006). These deepening-upward trends are also correlatable with time-equivalent deep-water carbonate sections in other areas around the London-Brabant Massif (Brown End Quarry, Staffordshire, England and Sovet and Salet sections, Dinant synclinorium, Belgium; Bábek et al. 2010). The transgressive patterns immediately above the Tn/V boundary suggest that the Viséan parts of the logged sections correlate with the lower parts of depositional sequence 5 of Hance et al. (2001).

The carbonate-dominated, turbidite-free succession in Lane was deposited in a much shallower depositional setting than the Rush and Bay Lane sections (Nolan, 1989) and the log response is consistent with the updip response of a carbonate system to regression (see above). Two regressive intervals can be seen in the section. The lower one, showing increasing trends in $\mathrm{K}$ and $\mathrm{Th}$ concentrations and siliciclastic admixture in carbonates (13 to 16 m; Fig. 9, uppermost Tournaisian MFZ 8) is followed by the latest Tournaisian (MFZ 8) marine flooding, which is indicated by a distinct shift towards low $\mathrm{K}$ and Th concentrations at the base of pure bioclastic limestones (transgressive systems tract, which may pass upwards into highstand systems tract). The late Tournaisian maximum flooding surface might be indicated by extremely high U/Th ratios at $\sim 6.5 \mathrm{~m}$ depth. The upper regressive event corresponds to the base of the Smuggler's Cave Conglomerate ( $2 \mathrm{~m}$, Fig. 9), which is Viséan in age and is associated with subaerial erosion (Marchant 1974, 1978; Nolan 1986). This interval in the Lane section is assumed to represent the shelf equivalent of the $\mathrm{Tn} / \mathrm{V}$ forced regression, which can be correlated with the situation in Rush and Bay Lane Quarry (Fig. 10) and with the boundary between depositional sequences 4 and 5 (Hance et al. 2001, 2002; Devuyst 2006).

\section{Conclusions}

The late Tournaisian in the Dublin Basin is characterized by a widespread occurrence of heterozoan and heterozoan-photozoan facies (Tober Colleen Formation, Lane Formation) with impoverished foraminiferal faunas indicating environments with higher nutrient levels which are typical of upwelling zones or regions with increased humidity. Both the facies and foraminiferal associations resemble those described in the Rundle Group in western Canada. The transition to heterozoan-photozoan facies with higher representation of dasycladaceans is typical for the base of Viséan and probably coincided with the change from a ramp into platform - rimmed basin (Somerville et al. 1992, Pickard et al. 1994, Strogen et al. 1996). The further development of carbonate platforms is recorded in the transition to photozoan facies higher in the Viséan MFZ9.

The biostratigraphic study supported by GRS logging, demonstrates a good applicability of the foraminiferal zonation of Devuyst \& Hance in Poty et al. (2006) even in the difficult settting of heterozoan facies with a taxonomically impoverished fauna. These facies have a negative impact on the entry of the MFZ 8 guide Eoparastaffella which is thus facially controlled and diachronous. In the absence of Eoparastaffella, Biseriella bristolensis can serve as another guide of MFZ 8; however, the species is not very common. Some problems are also connected with the entry of the MFZ 9 and Viséan guide Eoparastaffella simplex. First occurrences, both in Irish and other European sections, may be quite rare and often only more advanced evolutionary younger morphotypes are encountered (Devuyst 2006, Kalvoda et al. 2010). In its absence, the entry of Eoparastaffella ovalis M 2 following the latest Tournaisian entries of Lysella gadukensis, Eoparastaffella ovalis M3 and Eoparastaffella ex gr. florigena and preceding the FAD of Eoparastaffella asymmetrica enable high resolution biostratigraphy of the Tn-V boundary interval (Devuyst 2006, Kalvoda et al. 2010). The foraminiferal data from Bay Lane Quarry demonstrates that also the entry of the first archaediscids may be quite diachronous and thus the base of the Arundian stage may be difficult to identify.

The gamma-ray logs offer important added information to biostratigraphic correlation. They proved to be very useful tools for correlating the boundaries between depositional sequences 4 and 5 of Hance et al. (2001) just below the Tn-V boundary not only across the variable depositional settings of the Dublin Basin but also in other sections around the London-Brabant Massif (Bábek et al. 2010).

The good correlation of the sequences around the London-Brabant Massif may indicate a global glacioeustatic signal (Kalvoda 2002, Isaacson et al. 2008, Bábek et al. 2010). However, similar sequence boundaries have not yet been traced in Laurussia outside the London-Brabant Massif (Devuyst 2006). If glacioeustatic sea level changes 
did occur around the Tn/V boundary, the glacioeustatic signal may have been locally overprinted by tectonic processes connected with the transition to synorogenic flysch sedimentation (Moravia, Czech Republic; Kalvoda et al. 2010). Alternatively, the sea-level fluctuations may have been regionally restricted, reflecting extensional tectonics around the London-Brabant Massif (Leeder 1987, Nolan 1989, Gawthorpe et al. 1989).

\section{Acknowledgements}

This research was supported by grant project GACR 205/08/0182 and 205/08/J015. Jiří Povolný is thanked for preparing numerous high-quality thin sections. We thank Sean Cassidy, Irish Asphalt Ltd., for access to Bay Lane Quarry and for permission to publish. The paper has benefited from the comments of Marcus Aretz, Stephen Ehrenberg, Holger Forke and Ian Somerville.

\section{References}

Afshar, A. 1965. The geology of Rush. Unpublished M.Sc. thesis, Imperial College London.

Aschienazi-Polivoda, S., Edelman-Furstenberg, Y., AlmogiLabin, A. \& Benjamini, C. 2010. Characterization of lowest oxygen environments within ancient upwelling environments: Benthic foraminifera assemblages. Palaeogeography, Palaeoclimatology, Palaeoecology 289, 134-144.

DOI 10.1016/j.palaeo.2010.02.028

Bábek, O., Kalvoda, J., Aretz, M., Cossey, P.J., Devusyst, F.-X., Herbig, H.G. \& Sevastopulo, G.D. 2010. The correlation potential of magnetic susceptibility and outcrop gamma-ray logs at Tournaisian-Viséan boundary sections in Western Europe. Geologica Belgica 13(4), 291-308.

Bábek, O., Přikryl, T. \& Hladil, J. 2007. Progressive drowning of carbonate platform in the Moravo-Silesian Basin (Czech Republic) before the Frasnian/Famennian event: facies, compositional variations and gamma-ray spectrometry. $\mathrm{Fa}$ cies 53(2), 293-316. DOI 10.1007/s10347-006-0095-8

Baccelle, L. \& Bosellini, A. 1965. Diagrammi per la stima visiva della composizione Percentuale Nelle Rocce Sedimentarie. Annuali Dell Universita Di Ferrara 9, 59-62.

Beauchamp, B. 1994. Permian climatic cooling in the Canadian Arctic, 229-246. In Klein, G.D. (ed.) Pangea: Paleoclimate, tectonics, and sedimentation during accretion, zenith and breakup of a supercontinent. Geological Society of America Special Paper 288.

Beauchamp, B. \& Mamet, B.L. 1985. Foraminiferal biostratigraphy, Rundle Group, Lower Carboniferous, east-central British Columbia. Canadian Petroleum Geology Bulletin 33(2), 204-212.

BogusH, O.I. 1987. Systematical features and range of the genus Globoendothyra Reitlinger, 1959 (Foraminifera), 71-95. In KANYGin, A.V. (ed.) Mikrofauna i biostratigrafiya fanerozoya Sibiri i smezhnykh regionov. Nauka, Novosibirsk.

Brandley, R.T. \& Krause, P.E. 1997. Upwelling, thermoclines and wavesweeping on an equatorial carbonate ramp: Lower Carboniferous strata of western Canada, 365-390. In JAMES,
N.P. \& Clarke, J.A.D. (eds) Cool-water carbonates. SEPM, Special Publication 56.

Brazhnikova, N.E. \& Vdovenko, M.V. 1973. Early Viséan foraminifers of Ukraine. Naukova Dumka, Kiev. [in Ukrainian]

Brazhnikova, N.E. \& Rostovtseva, L.F. 1967. The study of early Viséan Endothyranopsis of the Donets Basin and other regions, 10-18. In Fauna of the early Viséan sediments of the Great Donbas. Naukova Dumka, Kiev. [in Russian]

BRENCKLE, P.L. 1997. What is Urbanella?, 11-13. In Ross, S.A., Ross, J.R.P. \& BRenckle, P.L. (eds) Late Paleozoic foraminifera, their biostratigraphy, evolution and paleoecology and the Mid-Carbonifreous boundary. Cushman Foundation for Foraminiferal Research Special Publication 36.

Brenckle, P.L. \& Gaetani, M. 2009. Refinements in biostratigraphy, chronostratigraphy, and paleogeography of the Mississippian (Lower Carboniferous) Mobarak Formation, Alborz Mountains, Iran. GeoArabia 14(3), 43-78.

Bridges, P.H., GutTeridge, P. \& Pickard, N.A.H. 1995. The environmental setting of Early Carboniferous mud-mounds, 171-190. In Monty, C.L.V., Bosence, D.W.J., Bridges, P.H. \& PRATt, B.R. (eds) Carbonate mud-mounds: their origin and evolution. International Association of Sedimentologists, Special Publication 23.

Carannante, G., Esteban, M., Milliman, J. \& Simone, L. 1988. Carbonate lithofacies as paleolatitude indicators: problems and limitations. Sedimentary Geology 60, 333-346. DOI 10.1016/0037-0738(88)90128-5

CoE, A.L. 2003. The Sedimentary Record of Sea-Level Change. 288 pp. The Open University and Cambridge University Press, Cambridge.

Conil, R. \& Lys, M. 1964. Matériaux pour l'étude micropaléontologique du Dinantien de la Belgique et de la France (Avesnois). Algues et Foraminifères Mémoire de l'Institut géologique de l'Université de Louvain 23, 1-279.

ConIL, R. 1976. Contribution à l'étude des foraminifères du Viséan de l'Irlande. Annales de la Société Géologique de Belgique 99, 467-479.

Conil, R., Austin, R., Lys, M. \& Rhodes, F. 1969. La limite des Etages Tournaisien et Viséen au stratotype de l'Assise de Dinant. Bulletin de la Société Belge de Géologie 77, 39-74.

Conil, R., Groessens, E. \& Pirlet, H. 1977. Nouvelle charte stratigraphique du Dinantien type de la Belgique. Annales de la Société géologique du Nord 96, 363-371.

Conil, R., Groessens, E., Laloux, M., Poty, E. \& Tourneur, F. 1991. Carboniferous guide foraminifera, corals and conodonts in the Franco-Belgian and Campine basins. Their potential for widespread correlation. Courier Forschungs-Institut Senckenberg 130, 15-30.

Conil, R., Groessens, E., Laloux, M. \& Poty, E. 1989. La limite Tournaisiaen/Viséen dans la région-type. Annales de la Société Géologique de Belgique 112, 177-189.

Conil, R. \& LeEs, A. 1975. Les transgressions Viséennes dans l'Ouest de l'Irlande. Annales de la Société Géologique de Belgique 97, 463-484.

Conil, R., Longerstaey, P.J. \& Ramsbottom, W.H.C. 1980. Matériaux pour l'étude micropaléontologique du Dinantien de Grande-Bretagne. Mémoires de l'Institut Géologique de l'Université de Louvain 30, 1-187.

ConiL, R. \& Lys, M. 1977. Les transgressions dinantiennes et leur influence sur la dispersion et l'évolution des foraminifères. Mémoires de l'Institut Géologique de l'Université de Louvain $29,9-55$. 
Delius, H., Kaupp, A., Muller, A. \& Wohlenberg, J. 2001. Stratigraphic correlation of Miocene to Plio-/Pleistocene sequences on the New Jersey shelf based on petrophysical measurements from ODP leg 174A. Marine Geology 175, 149-165. DOI 10.1016/S0025-3227(01)00115-3

Devuyst, F.X. 2006. The Tournaisian-Viséan boundary in Eurasia: Definition, biostratigraphy, sedimentology and early evolution of the genus Eoparastaffella (foraminifer). Ph.D. thesis, Catholic University of Louvain.

Devuyst, F.X., Hance, L., Hou, H.,Wu, X., Tian, S., Coen, M. \& Sevastopulo, G. 2003. A proposed Global Stratotype Section and Point for the base of the Viséan Stage (Carboniferous): the Pengchong section, Guangxi, South China. Episodes 26, $105-115$.

Devuyst, F.X. \& Kalvoda, J. 2007. Early evolution of the genus Eoparastaffella (Foraminifera) in Eurasia: the 'interiecta group' and related forms, late Tournaisian to early Viséan (Mississippian). Journal of Foraminiferal Research 37(1), 69-89. DOI 10.2113/gsjfr.37.1.69

Doveton, J.H. 1994. Geologic log interpretation SEPM. Short Course Notes 29, 1-169.

Doveton, J.H. \& Merriam, D.F. 2004. Borehole petrophysical chemostratigraphy of Pennsylvanian black shales in the Kansas subsurface. Chemical Geology 206, 249-258.

DOI 10.1016/j.chemgeo.2003.12.027

EhrenberG, S.N. \& Svana, T.A. 2001. Use of spectral gammaray signature to interpret stratigraphic surfaces in carbonate strata; an example from the Finnmark carbonate platform (Carboniferous-Permian), Barents Sea. American Association of Petroleum Geologists Bulletin 85, 295-308.

Ehrenberg, S.N., Svana, T.A. \& Swart, P.K. 2008. Uranium depletion across the Permian-Triassic boundary in Middle East carbonates: Signature of oceanic anoxia. American Association of Petroleum Geologists Bulletin 92, 691-707.

Fabricius, I.L., Fazladic, L.D., Steinholm, A. \& Korsbech, U. 2003. The use of spectral natural gamma-ray analysis in reservoir evaluation of siliciclastic sediments: A case study from the Middle Jurassic of the Harald Field, Danish Central Graben. Geological Survey of Denmark and Greenland Bulletin 1, 349-366.

Faulkner, T.J., Wright, V.P., Peeters, C. \& Garvie, L. 1990. Cryptic exposure horizons in the Carboniferous Limestone of Portishead. Avon Geological Journal 25, 1-17. DOI $10.1002 /$ gj.3350250102

FiET, N. \& GoRIN, G.E. 2000. Gamma-ray spectrometry as a tool for stratigraphic correlations in the carbonate dominated, organic-rich, pelagic Albian sediments in Central Italy. Eclogae Geologae Helvetiae 93, 175-181.

Gawthorpe, R.L., Guteridge, P. \& Leeder, M.R. 1989. Late Devonian and Dinantian basin evolution in northern England and North Wales, 1-24. In Arthurton, R.S., Gutteridge, P. \& Nolan, S.C. (eds) The Role of Tectonics in Devonian and Carboniferous Sedimentation in the British Isles. Yorkshire Geological Society Occasional Publication 6.

George, T.N., Johnson, G.A.L., Mitchell, M., Prentice, J., Ramsbottom, W.H.C., Sevastopulo, G.D. \& Wilson, R.B. 1976. A correlation of Dinantian rocks in the British Isles. Special Report of the Geological Society of London 7, 1-86.

Guasti, E., Kouwenhoven, T.J., Brinkhuis, H. \& SpeiJer, R.P. 2005. Paleocene sea-level and productivity changes at the southern Tethyan margin (El Kef, Tunisia). Marine Micropaleontology 55, 1-17. DOI 10.1016/j.marmicro.2005.01.001
GuTSCHICK, R.C. \& SANDBERG, C.A. 1983. Mississippian continental margins of the conterminous United States, 79-96. In STANLEY, D.J. \& Moore, G.T. (eds) The Shelfbreak Margin-Critical Interface on Continental Margins. Society of Economic Paleontologists and Mineralogists, Special Publication 33.

Halfar, H., Godinez-Orta, L., Mutti, M., Valdez-Holguin, J.E. \& BorgES, J.M. 2004. Nutrients and temperature controls on modern carbonate production: an example from the Gulf of California, Mexico. Geology 32, 213-216. DOI 10.1130/G20298.1

Halgedahl, S.L., JarRard, R.D., Brett, C.E. \& Allison, P.A. 2009. Geophysical and geological signatures of relative sea level change in the upper Wheeler Formation, Drum Mountains, West-Central Utah: A perspective into exceptional preservation of fossils. Palaeogeography, Palaeoclimatology, Palaeoecology 277(1-2), 34-56. DOI 10.1016/j.palaeo.2009.02.011

Hance, L., Laloux, M., Muchez, P., Groessens, E., Peeters, C. \& Роту, E. 1994 An outline of the Molinacian (Upper Tournaisian-Lower Viséan ) in southern Belgium. Introduction to a field excursion in honour of Prof. Dr. Raphael Conil 12 October, 1991. Mémoires de l'Institute Géologique de l'Univerité Catholique de Louvain 35, 27-50.

Hance, L. 1988. Le Moliniacien du Synclinorium de Dinant (Belgique) de la région dinantaise à la vallée de l'Ourthe. Mémoires de l'Institut Géologique de l'Université de Louvain 33, 1-91.

Hance, L. 1997. Eoparastaffella, its evolutionary pattern and biostratigraphic potential, 59-62. In Ross, C.A., Ross, J.R.P. \& Brenckle, P.L. (eds) Late Paleozoic Foraminifera: Their Biostratigraphy, Evolution, and Paleoecology and the MidCarboniferous Boundary. Cushman Foundation for Foraminiferal Research, Special Publication 36.

Hance, L., Muchez, P., Hou, H.F. \& Wu, X.H. 1997. Biostratigraphy, sedimentology and sequence stratigraphy of the Tournaisian-Viséan transitional strata in South China (Guangxi). Geological Journal 32, 337-357.

DOI 10.1002/(SICI)1099-1034(199712)32:4<337::AID-GJ748 $>3.0 . \mathrm{CO} ; 2-6$

Hance, L., Poty, E. \& Devuyst, F.X. 2002. Sequence stratigraphy of the Belgian Lower Carboniferous - tentative correlation with the British Isles, 41-51. In HiLls, L.V., Henderson, C.M. \& Bamber, E.W. (eds) Carboniferous and Permian of the World. Canadian Society of Petroleum Geologists, Memoirs 19.

Hance, L., Poty, E. \& Devuyst, F.X. 2001. Stratigraphie séquentielle du Dinantien type (Belgique) et corrélation avec le Nord de la France (Boulonnais, Avesnois). Bulletin de la Société Géologique de France 172(4), 411-426. DOI 10.2113/172.4.411

Hladil, J., Geršl, M., Strnad, L., Frána, J., Langrová, A. \& SPIŠIAK, J. 2006. Stratigraphic variation of complex impurities in platform limestones and possible significance of atmospheric dust: a study with emphasis on gamma-ray spectrometry and magnetic susceptibility outcrop logging (EifelianFrasnian, Moravia, Czech Republic). International Journal of Earth Sciences 95, 703-723. DOI 10.1007/s00531-005-0052-8

IsaAcson, P.E., Díaz-Martínez, E., Grader, G.W., Kalvoda, J., BÁbeK, O. \& Devuyst, F.X. 2008. Late Devonian-earliest Mississippian glaciation in Gondwanaland and its biogeographic consequences. Palaeogeography, Paleocology, 
Paleoclimatology 268, 126-142.

DOI 10.1016/j.palaeo.2008.03.047

Ivanova, R.M. 2008. Lower Carboniferous of the TumenKustanai Trough's Borovskaya Subzone. Litosfera 2, 3-24. [in Russian]

JAMES, N.P. 1997. The cool-water carbonate depositional realm, 1-20. In JAMEs, N.P. \& Clarke, J.A.D. (eds) Coolwater carbonates. SEPM, Special Publication 56.

Jones, G.L. \& SOMERvilLe, I.D. 1996. Irish Dinantian Biostratigraphy: practical application, 371-385. In STROGeN, P., Somerville, I.D. \& Jones, G.L. (eds) Recent Advances in Lower Carboniferous Geology. Geological Society of London, Special Publications 107.

Jones, G.L., Somerville, I.D. \& Strogen, P. 1988. The Lower Carboniferous (Dinantian) of the Swords area: Sedimentation and tectonics of the Dublin Basin, Ireland. Geological Journal 23, 221-248.

DOI 10.1002/gj.3350230304

Kabanov, P. 2009. Benthic carbonate facies of the Phanerozoic: review and example from the Carboniferous of the Russian Platform. Stratigrafiya Geologicheskaya Korrelyatsiya 17(5), 41-59.

KalvodA, J. 1982. Contribution to the position of the Lower Carboniferous foraminiferal fauna from Moravia in reconstructions of the paleobiogeographical dispersal of foraminifera in Europe. Acta Universitatis Carolinae, Paleontologia 4, 329-340.

Kalvoda, J. 1983. Preliminary foraminiferal zonation of the Upper Devonian and Lower Carboniferous in Moravia. Zemni plyn a nafta, Knihovnička 4, 23-42.

Kalvoda, J. 2002. Late Devonian-early Carboniferous foraminiferal fauna: zonations, evolutionary events, paleobiogeography and tectonic implications. Folia Facultatis scientiarium naturalium Universitatis Masarykianae Brunensis, Geologia 39, 1-213.

Kalvoda, J., Devuyst, F.X., BÁbek, O., Dvořák, L., RaK, Š. \& REZ, J. 2010. High-resolution biostratigraphy of the Tournaisian-Visean (Carboniferous) boundary interval, Mokrá quarry, Czech Republic. Geobios 43, 317-331.

DOI 10.1016/j.geobios.2009.10.008

Koptíková, L., BÁbeK, O., Hladil, J. \& Slavík, L. 2010. Stratigraphic significance and resolution of spectral reflectance logs in Lower Devonian carbonates of the Barrandian area, Czech Republic; a correlation with magnetic susceptibility and gamma-ray logs. Sedimentary Geology 225, 83-98. DOI 10.1016/j.sedgeo.2010.01.004

Kulagina, E.I., Gibshman, N.B. \& Pazukhin, V.N. 2003. Foraminiferal zonal standard for Lower Carboniferous of Russia and its correlation with conodont zonation. Rivista Italiana di Paleontologia e Stratigrafia 109, 173-186.

LEEDER, M.R. 1987. Tectonic and palaeogeographic models for Lower Carboniferous Europe, 1-20. In Miller, J., AdAms, A.E. \& Wright, V.P. (eds) European Dinantian Environments. Wiley, Chichester.

LÜning, S., AdAmson, K. \& Craig, J. 2003. Frasnian organic-rich shales in North Africa; regional distribution and depositional model, 165-184. In Artur, T., MacGregor-Duncan, S. \& CAmeron, N.R. (eds) Petroleum geology of Africa; new themes and developing technologies. Geological Society of London, Special Publications 207.

Lyadova, R.A. \& Pogorelov, Y.I. 1990. Lower Viséan deposits of the Yabur section in the Vishera river basin (Northern Ural).
In Papulov, G.I. \& Chuvashov, B.I. (eds) Boundaries of Carboniferous Biostratigraphical Subdivisions in the Urals. Sbornik nauchykh trudov, Uralskoe Otdelenie AN SSSR, 3-34. [in Russian]

Malakhova, N.P. 1975. Foraminifers of the lower Viséan of the eastern slopes of the southern Urals. Trudy Instituta Geologii $i$ Geokhimii 112, 5-45. [in Russian]

Mamet, B. 1969. Microfaunal zonation of the Lower Carboniferous Rush Slates and Conglomerate (Eire). Scientific Proceedings Royal Dublin Society 3A, 237-245.

Mamet, B.L., Bamber, E.W. \& Macqueen, R.W. 1986. Microfacies of the Lower Carboniferous Banff Formation and Rundle Group, Monkman Pass map area, northeastern British Columbia. Geological Survey of Canada Bulletin 353, 1-93.

Marchant, T.R. 1974. Preliminary note on the micropaleontology of the Dinantian Dublin Basin, Ireland. Annales de la Société Géologique de Belgique 97, 447-461.

MARChANT, T.R. 1978. The stratigraphy and micropalaeontology of the Lower Carboniferous (Courceyan-Arundian) of the Dublin Basin, Ireland. Unpublished Ph.D. thesis, Trinity College, Dublin.

Nolan, S.C. 1986. The Carboniferous geology of the Dublin area. Unpublished Ph.D. thesis, Trinity College, Dublin.

NolAn, S.C. 1989. The style and timing of Dinantian synsedimentary tectonics in the eastern part of the Dublin Basin, Ireland, 83-98. In Arthurton, R.S., GUTTERIDGE, P. \& NolAn, S.C. (eds) The Role of Tectonics in Devonian and Carboniferous Sedimentation in the British Isles. Yorkshire Geological Society Occasional Publication 6.

Paproth, E., Conil, R., Bless, M.J.M., Boonen, P., Bouckaert, J., Carpentier, N., Coen, M., Delcambre, B., Deprijck, C., Deuzon, S., Dreesen, R., Groessens, E., Hance, L., HenneBert, M., Hibo, D., Hahn, G., Hahn, R., Hislaire, O., Kasig, W., LalouX, M., Lauwers, A., Lees, A., Lys, M., Op De BeeK, K., Overlau, P., Pirlet, H., Poty, E., Ramsbottom, W., Streel, M., Swennen, R., Thores, J., Vanguestaine, M., Van SteEnwinke, M. \& VIESLET, J.L. 1983. Bio-and lithostratigraphic subdivisoins of the Dinantian in Belgium, a review. Annales de la Société Géologique de Belgique 106, 185-239.

Pedley, M. 1998. A review of sediment distributions and processes in Oligo-Miocene ramps of southern Italy and Malta (Mediterranean divide), 163-179. In Wright, V.P. \& Burchette, T.P. (eds) Carbonate Ramps. Geological Society of London, Special Publication 149.

Phillips, W.E.A. \& Sevastopulo, G.D. 1986. The stratigraphic and structural setting of Irish mineral deposits, 1-30. In ANDrew, C.J., Crowe, R.W.A., Finlay, S., Pennell, W.M. \& Pyne, J. (eds) Geology and genesis of mineral deposits in Ireland, Dublin. Irish Association for Economic Geology.

PickARD, N.A.H. 1996. Evidence for microbial influence on the development of Lower Carboniferous buildups, 65-82. In Strogen, P., Somerville, I.D. \& Jones, G.L. (eds) Recent Advances in Lower Carboniferous Geology. Geological Society of London, Special Publication 107.

Pickard, N.A.H., Rees, J.G., Strogen, P., Somerville, I.D. \& JONES, G.L. 1994. Controls on the evolution and demise of Lower Carboniferous carbonate platforms, northern margin of the Dublin Basin, Ireland. Geological Journal 29, 93-117. DOI 10.1002/gj.3350290202

Postoyalko, M.V. 1975. Foraminifers and stratigraphy of the early Viséan of the western slope of the Urals. Trudy Instituta Geologii i Geokhimii 112, 110-143. [in Russian] 
Postoyalko, M.V. \& Cherepanova, N.A. 1990. K stratigrafii nizhnego vise vostochnogo sklona Srednego Urala. Granitsy biostratigraficheskich podrazdelenii karbona Urala. Sverdlovsk, IgiG UrO AN SSSR 1990, 35-56. [in Russian]

Poty, E., Devuyst, F.X. \& Hance, L. 2006. Upper Devonian and Mississippian foraminiferal and rugose coral zonations of Belgium and Northern France: a tool for Eurasian correlations. Geological Magazine 143, 829-857.

DOI 10.1017/S0016756806002457

RAмsвоттом, W.H.C. 1973. Transgressions and regressions in the Dinantian: a new synthesis of British Dinantian stratigraphy. Proceedings of the Yorkshire Geological Society 39, 567-607. DOI 10.1144/pygs.39.4.567

Rauser-Chernoussova, D.M. 1948. Data on the foraminiferal fauna of the Carboniferous sediments of Central Kazakhstan. Trudy Instituta geologicheskikh nauk 66(21), 1-28. [in Russian]

RIDER, M.H. 1999. The geological interpretation of well logs. 288 pp. Whittles Publishing Services, Dunbeath.

RiLEY, N.J. 1995. Foraminiferal biostratigraphy of the Chadian stage stratotype (Dinantian), Chatburn, northwest England. Bulletin de la Société belge de Géologie 103, 13-49.

Sando, W.J., Mamet, B.L. \& Dutro, J.T. 1969. Carboniferous megafaunal and microfaunal zonation in the Northern Cordillera of the United States. U.S. Geological Survey Professional Paper 613-E, 1-29.

SARG, J.F. 1988. Carbonate sequence stratigraphy, 155-182. In Wilgus, C.K., Hastings, B.S., Kendall, C.G.S.C., PosaMENTIER, H.W., Ross, C.A. \& VAN WAGOner, J.C. (eds) Sea-Level Changes: An Integrated Approach. SEPM Special Publication 42.

Schlager, W. 2003. Benthic carbonate factories of the Phanerozoic. International Journal of Earth Sciences 92, 445-464. DOI 10.1007/s00531-003-0327-X

Sevastopulo, G.D. \& Wyse Jackson, P.N. 2009. Carboniferous: Mississippian (Tournaisian and Viséan), 215-268. In HoLLAND, C.H. \& SANDERS, I.S. (eds) The Geology of Ireland. $2^{\text {nd }}$ revised edition. Academic Press, Dunedin.

SCHLAGER, W. 2003. Benthic carbonate factories of the Phanerozoic. International Journal of Earth Sciences 92, 445-464. DOI 10.1007/s00531-003-0327-x

Simpson, J. \& KalvODA, J. 1987. Sedimentolgy and foraminiferal biostratigraphy of the Arundian (Dinantian) stratotype, 226-237. In HART, M. (ed.) Micropalaeontology of Carbonate Environments. British Micropalaeotological Society, Ellis Horwood.

Sмyth, L.B. 1949. The Carboniferous system in north County Dublin. Quarterly Journal of the Geological Society of London 105, 295-324.

DOI 10.1144/GSL.JGS.1949.105.01-04.12

Sмyth, L.B. 1951. A Viséan cephalopod fauna in the Rush Slates of Co Dublin. Proceedings of the Royal Irish Academy 53B, 289-309.

Somerville, I.D., Pickard, N.A.H., Strogen, P. \& Jones, G.L. 1992. Early to mid-Viséan shallow water platform buildups, north Co Dublin. Ireland Geological Journal 27, 151-172.

Somerville, I.D., Strogen, P. \& Jones, G.L. 1992. Biostratigraphy of Dinantian limestones and associated volcanic rocks in the Limerick Syncline. Ireland Geological Journal 27, 201-220.

Stanton, JR. R.J. 2006. Nutrient models for the development and location of ancient reefs. Géologie Alpine 3, 191-206.
Stepanova, T.I., Kucheva, N.A. \& Postoyalko, M.V. 2008. Lithological-stratigrafic features of Early Viséan Rezh River basin carbonaceous deposits (Mironovian formation) in the Middle Urals eastern slope. Litosfera 5, 15-38. [in Russian]

Strogen, P., Jones, G.L. \& Somerville, I.D. 1990. Stratigraphy and sedimentology of Lower Carboniferous (Dinantian) boreholes from west Co Meath. Ireland Geological Journal 25, 103-137.

Strogen, P., Somerville, I.D., Jones, G.L. \& Pickard, N.A.H. 1995. The Lower Carboniferous (Dinantian) stratigraphy and structure of the Kingscourt Outlier. Ireland Geological Journal 30, 1-23.

Strogen, P., Somerville, I.D., Pickard, N.A.H., Jones, G.L. \& Fleming, M. 1996. Controls on ramp, platform and basin sedimentation in the Dinantian of the Dublin Basin and Shannon Trough, Ireland, 263-279. In Strogen, P., Somerville, I.D. \& Jones, G.L. (eds) Recent Advances in Lower Carboniferous Geology. Geological Society of London, Special Publication 107.

Thibal, J., Etchecopar, A., Pozz, J.P., Barthes, V. \& PocaCHARD, J. 1999. Comparison of magnetic and gamma ray logging for correlations in chronology and lithology: example from the Aquitanian Basin (France). Geophysical Journal International 137, 839-846.

DOI 10.1046/j.1365-246x.1999.00828.x

Tilsey, J.W. \& Korn, D. 2009. Chadian (Tournaisian - Viséan, Carboniferous) ammonoids from the Milldale Limestone Formation of the southern Peak District, England. Proceedings of the Yorkshire Geological Society 57, 217-234.

DOI 10.1144/pygs.57.3-4.217

Vdovenko, M.V. 1980. The Viséan Stage Zonal subdivision and palaeozoogeographical zonation based on Foraminifera. Akademiya nauk Ukrainskoy SSR, Institut geologicheskikh nauk, Kiev. [in Ukrainian]

Vissarionova, A.I. 1948. Stratigraphical significance of foraminifers for the Viséan of the Tuimasin region. Trudy Instituta Geologicheskikh nauk 62(19), 70-83. [in Russian]

Westphal, H., Halfar, J. \& Freiwald, A. 2010. Heterozoan carbonates in subtropical to tropical settings in the present and past. International Journal of Earth Sciences 99, 153-159. DOI 10.1007/s00531-010-0563-9

Work, D.M. 2008. Secretary Editor's Report 2007-2008. Newsletter on Carboniferous Stratigraphy 26, 4.

WRIGHT, V.P. 1990. Equatorial aridity and climatic oscillations during the early Carboniferous, southern Britain. Journal of the Geological Society, London 147, 359-365.

DOI 10.1144/gsigs.147.2.0359

Wright, V.P. 1991. Comment and reply on "Probable Influence of Early Carboniferous (Tournaisian-Early Visean) Geography on the Development of Waulsortian and Waulsortian-like Mounds". Geology 19, 413.

DOI 10.1130/0091-7613(1991)019<0413:CAROPI >2.3.CO;2

WRIGHT, V.P. 1994. Early Carboniferous carbonate systems: an alternative to the Cainozoic paradigma. Sedimentary Geology 93, 1-5. DOI 10.1016/0037-0738(94)90025-6

Wright, V.P. \& FAulKner, T.J. 1990. Sediment dynamics of Early Carboniferous ramps: a proposal. Geological Journal 25, 139-144. DOI 10.1002/gj.3350250205

Wright, V.P. \& BuRgESS, P.M. 2005. The carbonate factory continuum, facies mosaics and microfacies: an appraisal of some of the key concepts underpinning carbonate sedimentology. Facies 51, 17-23. DOI 10.1007/s10347-005-0049-6 